\title{
Pluton-dyke relationships in a Variscan granitic complex from AMS and gravity modelling. Inception of the extensional tectonics in the South Armorican Domain (France)
}

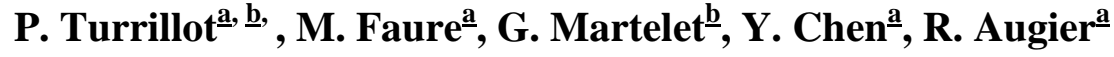 \\ a Institut des Sciences de la Terre d'Orléans (ISTO), Université d'Orléans, CNRS/INSU, \\ Université François Rabelais Tours, UMR6113, 45071 Orléans cedex 2, France \\ ${ }^{\mathrm{b}}$ BRGM-GEO/G2R, BP 36009, 45060 Orléans cedex 2, France
}

\begin{abstract}
The Carnac granitic Complex (South Armorican Domain, Western France) was emplaced during Late Carboniferous times in the deepest Variscan unit, roofed by two major extensional shear zones. Through the acquisition and interpretation of field data, Anisotropy of Magnetic Susceptibility and gravity data, emphasized by petrological and structural observations, we address the emplacement model and possible magmatic processes involved between dyking to massive plutonism in a synkinematic context. Gravity modelling highlights an overall eastward thinning of the pluton, and several deep zones in the western part of the complex, interpreted as the pluton feeder zones. The internal granitic fabric, developed in a sub-solidus state, shows marked planar-linear anisotropy, consistent with a vertical shortening in the WNW-ESE regional stretching regime and eastward magma spreading. This study documents the occurrence of numerous NNE-SSW trending dykes within the eastern part of the pluton, suggesting that this granitic Complex formed by the coalescence of dykes oriented perpendicular to the regional stretching direction, and thus interpreted as large-scale "tension gashes". The synkinematic character of the Carnac Complex intrusion, recently dated at ca. $319 \pm 6 \mathrm{Ma}$, thus times the inception of the late-orogenic extensional deformation experienced in the whole South Armorican Domain.
\end{abstract}

Keywords: Anisotropy of magnetic susceptibility (AMS); 2D gravity modelling; Synkinematic intrusion; Pluton-dyke relationships; Variscan belt; Armorican massif

\section{Introduction}

In many collisional orogens, the thickened crust experiences extensional tectonics during lateorogenic stages, coeval with a widespread crustal melting, responsible for the emplacement of a large volume of granitic magma in the middle to upper crust (e.g. [Le Fort, 1981] , [Harris and Massey, 1994] , [Faure, 1995] , [Whitney et al., 2004] , [Brown, 2005] and [Faure et al., 2008] ). The tectonic framework of the late-orogenic evolution is then dominated by extensional tectonics leading to the formation of large-scale extensional shear zones that accommodate the stretching of the continental crust (e.g. [Wernicke, 1981] , [Lister et al., 1984] and [Malavieille, 1993] ).

Internal fabrics of granitoids are often regarded as representative strain markers to investigate crustal deformation (e.g. [Cloos, 1925] , [Brun and Pons, 1981] , [Gapais and Barbarin, 1986] , [Paterson et al., 1989] , [Faure and Pons, 1991] , [Faure, 1995] , [Talbot et al., 2005a] and [Talbot et al., 2005b] ). Dyke swarms that may surround the granitic plutons can be used to 
provide a minimum estimate of crustal extension (Passchier, 1990). During the last decades, the structural and genetic relationships between plutons and their associated dyke swarm have been widely investigated ( [Clemens and Mawer, 1992] , [Petford et al., 1993] , [Petford et al., 2000] , [Rubin, 1995] , [Petford, 1996] , [Talbot et al., 2005b] and [Bartley et al., 2006] ). It was argued that the dykes are either fed by magma coming from the pluton (e.g. [Baker, 1998], [Clemens and Mawer, 1992] and [Rubin, 1995] ) or play a significant role in building the pluton (e.g. Petford et al., 2000).

This study focuses on the Variscan Carnac Complex, made of a granitic pluton and its surrounding dyke array that was emplaced in the South Armorican Domain during the late tectonic evolution of the Variscan belt (Turrillot et al., 2009). Using the Anisotropy of Magnetic Susceptibility (AMS), the mineral preferred orientation of the Variscan Carnac granitic pluton and of its surrounding dykes has been determined. Based on geological mapping, recent studies suggested that the Carnac Complex emplacement may record initial stages of the late-orogenic extensional tectonics (Augier et al., in press). The AMS survey enabled us to better understand the late-stage internal structure and fabric orientations developed within the crystallizing magma chamber, which will, in turn, be used to i) determine the principal strain axes that develop during the emplacement of the Carnac Complex and ii) characterize the relationships between the pluton and its dyke swarm. However, the magnetic fabric provides structural information restricted to the exposed level of the complex, but does not inform on the deep structures such as the geometry of the feeder zones or the pluton thickness variations. Therefore, a combined AMS and gravity study of the Carnac Complex is achieved; it will provide new insights on the pluton shape at depth, and will improve the understanding of the complex overall architecture in the context of a synkinematic emplacement. Combined with microstructural observations, the role of magma dynamics-related deformation and/or regional stretching on the fabric development both in the pluton and in the dyke swarm can be discussed. These new data enable us to propose an emplacement model, which is also discussed in terms of regional implications in the light of the extensional tectonic framework that has been previously proposed for this area of the South Armorican Domain ( [Gapais et al., 1993] and [Turrillot et al., 2009] ).

\section{Geological setting}

\subsection{General framework}

The orogenic evolution of the European Variscides includes Ordovician rifting, Silurian subduction, Silurian-Devonian multiple collisions, Late Devonian-Carboniferous intracontinental deformation, and Upper Carboniferous late-orogenic extension ( [Dewey and Burke, 1973] , [Matte, 1986] , [Matte, 1991 , [Matte, 2001] , [Gapais et al., 1993] , [Faure, 1995] , [Cagnard et al., 2004] and [Faure et al., 2005] ). The French Massif Armoricain is classically subdivided into several tectono-metamorphic domains by two major dextral strikeslip shear zones active during the Upper Carboniferous times, namely, the North Armorican Shear Zone (NASZ), and the South Armorican Shear Zone (SASZ) that splits into a WNWESE northern branch and a NW-SE southern branch (Fig. 1a; [24, [Watts and Williams, 1979] and [Jégouzo, 1980] ). However, these Carboniferous shear zones do not represent suture zones or plate boundaries. Concerning the Early Variscan collisional events, the Nortsur-Erdre fault is considered as the suture zone between Central Armorican and South Armorican Domain (Fig. 1a) ( [Faure et al., 2005] , [Faure et al., 2008] and [Ballèvre et al., 2009] ). 


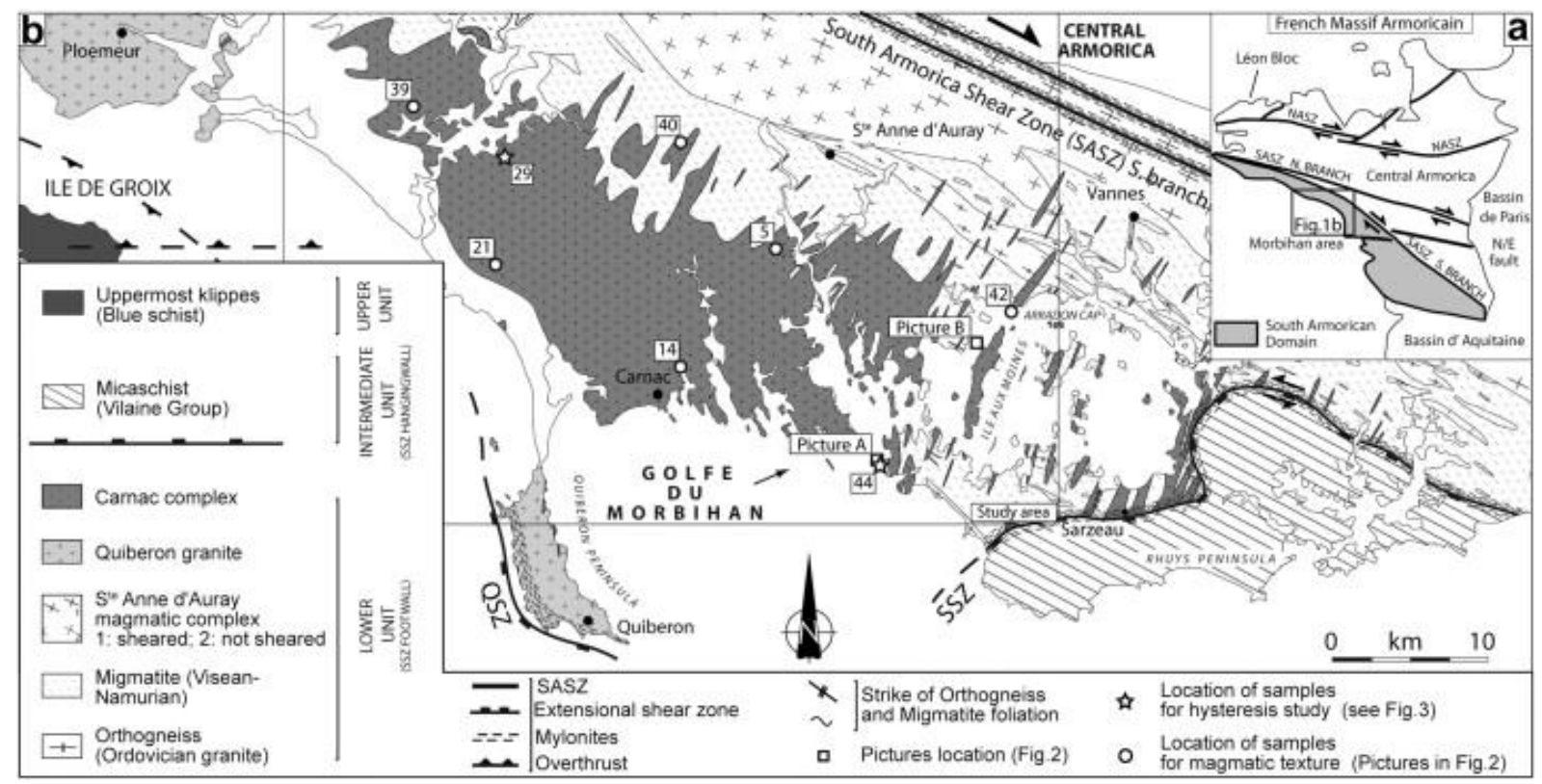

Fig. 1. :(a) Simplified map of the Massif Armoricain. NASZ: North Armorican Shear Zone, SASZ: South Armorican Shear Zone, N. Branch: Northern Branch, S. Branch: Southern Branch; (b) Structural map of the Morbihan area in the South Armorican domain (Modified from Turrillot et al., 2009). The main tectonostratigraphic units and their internal features are depicted. The Intermediate and the Lower units are separated by the extensional Sarzeau Shear Zone (SSZ) in the Rhuys Peninsula, and the Quiberon Shear Zone (QSZ) in the Quiberon Peninsula.

The South Armorican Domain is limited to the north by the southern branch of the SASZ (Fig. 1a; [Berthé et al., 1979] and [Jégouzo, 1980] ). There, several tectono-metamorphic units are recognized from top to bottom (Fig. 1b; e.g. [24], [Le Corre et al., 1991] and [Ballèvre et al., 1994] ): (1) Upper units characterized by well preserved HP-LT metamorphic rocks in the Bois de Céné, and Ile de Groix blueschist klippes (Bosse et al., 2002), and in Vendée and Belle-Ile-en-Mer porphyroids (Le Hébel et al., 2002); (2) Intermediate units or "Schistes de la Vilaine" group equilibrated upon a MP-MT Barrovian geothermal gradient ( [Triboulet and Audren, 1988] and [36] ; Brown and Dallmeyer, 1996); and (3) Lower unit of HT-MP rocks consisting of migmatites (i.e. metatexites) and migmatitic granites (i.e. diatexites) intruded by large volumes of late to post- migmatitic granites (e.g. [Audren and Le Métour, 1976] and [Marchildon and Brown, 2003] ).

Unlike Central Armorica, the South Armorican Domain underwent extensional tectonics during the last stage of the Variscan orogenic evolution (e.g. [Gapais et al., 1993] , [Cagnard et al., 2004] and [Turrillot et al., 2009] ). The overall tectonic framework of the South Armorican Domain consists of Lower Unit migmatites and granites, exposed in tectonic windows overlain by the Intermediate Unit. At the regional scale, a widespread extension is well documented in the Sables d'Olonne area where it is accommodated by a pervasive thinning of the entire metamorphic sequence (Cagnard et al., 2004), whereas in the Morbihan area, Lower Unit high-grade rocks are roofed by localized top-to-the-WNW, and top-to-the- 
ESE extensional shear zones, namely, the Quiberon Shear Zone (QSZ), and the Sarzeau Shear Zone (SSZ), respectively ( [Gapais et al., 1993] and [Turrillot et al., 2009] ).

\subsection{The Morbihan area}

In the Morbihan area, the Intermediate Unit forms the SSZ hanging wall. This overlying unit mainly consists of garnet-micaschists belonging to the "Schistes de la Vilaine" group ( [2] , [Triboulet and Audren, 1988] and [4] ). The sub-horizontal foliation and WNW-ESE lineation (Audren, 1987) are interpreted as remnant features of a Devonian thrusting event ( [Brun and Burg, 1982] and [Vauchez et al., 1987] ), equivalent to the D2 event of Faure et al. (2005). In the SSZ footwall, the Lower Unit, which is bounded to the north by the SASZ strike-slip fault, consists of subvertical, NW-SE striking, migmatites derived from metasediments and rare orthogneiss bodies ( [Brown, 1983] , [Peucat, 1983] , [Jégouzo et al., 1986] , [2] , [Jones and Brown, 1990] and [Guerrot et al., 1997] ), dated to Early Ordovician (ca. $463 \pm 6 \mathrm{Ma}$; Peucat, 1983). In the Lower Unit, metamorphic peak-conditions, estimated at 9-10 kbar and 750-800 ${ }^{\circ} \mathrm{C}$ ( [2] , [Triboulet and Audren, 1988] , [Jones and Brown, 1989] , [Jones and Brown, 1990], [Brown and Dallmeyer, 1996] and [Johnson and Brown, 2004] ), were followed by a stepped retrograde P-T path involving decompression and a second episode of melt generation around $\sim 4 \mathrm{kbar}$ and $700-750{ }^{\circ} \mathrm{C}$ ( [Brown and Dallmeyer, 1996] and [Johnson and Brown, 2004] ).

Crustal melting, dated at $322 \pm 3$ Ma by monazite U-Th/Pb in-situ method (Turrillot et al., 2009) produced large volumes of anatectic granite all over the migmatitic area. These granitic bodies, with a size from $1 \mathrm{~m}$ to more than $3 \mathrm{~km}$, are elongated along the migmatitic foliation. One of these bodies forms a $70 \mathrm{~km}$ elongated pluton regionally known as the $S^{\text {te }}$-Anne d'Auray magmatic complex (Fig. 1b; [Le Métour, 1977] and [4] ). The migmatites crossed the solidus at $\sim 3.5 \mathrm{kbar}$ and $660{ }^{\circ} \mathrm{C}$ (Brown and Dallmeyer, 1996). Farther to the south, a WNWESE elongated magmatic body of ca. $20 \times 50 \mathrm{~km}$, known as the Carnac Complex (Fig. 1b), intrudes into the migmatites (Fig. 2a; [Audren and Le Métour, 1976] and [4] ). Monazite U$\mathrm{Th} / \mathrm{Pb}$ time-constraints yielded emplacement ages of the Carnac Complex at $319 \pm 6 \mathrm{Ma}$ ( [Turrillot et al., 2009] and [4] ). Conventional ${ }^{40} \mathrm{Ar} /{ }^{39} \mathrm{Ar}$ analyses on white micas from the undeformed Carnac Complex granite provided cooling ages at $\sim 305 \mathrm{Ma}$ (Turrillot, 2010). In the southwest part of the study area, the Quiberon leucogranite also intrudes into the migmatites but its emplacement age remains unknown. 

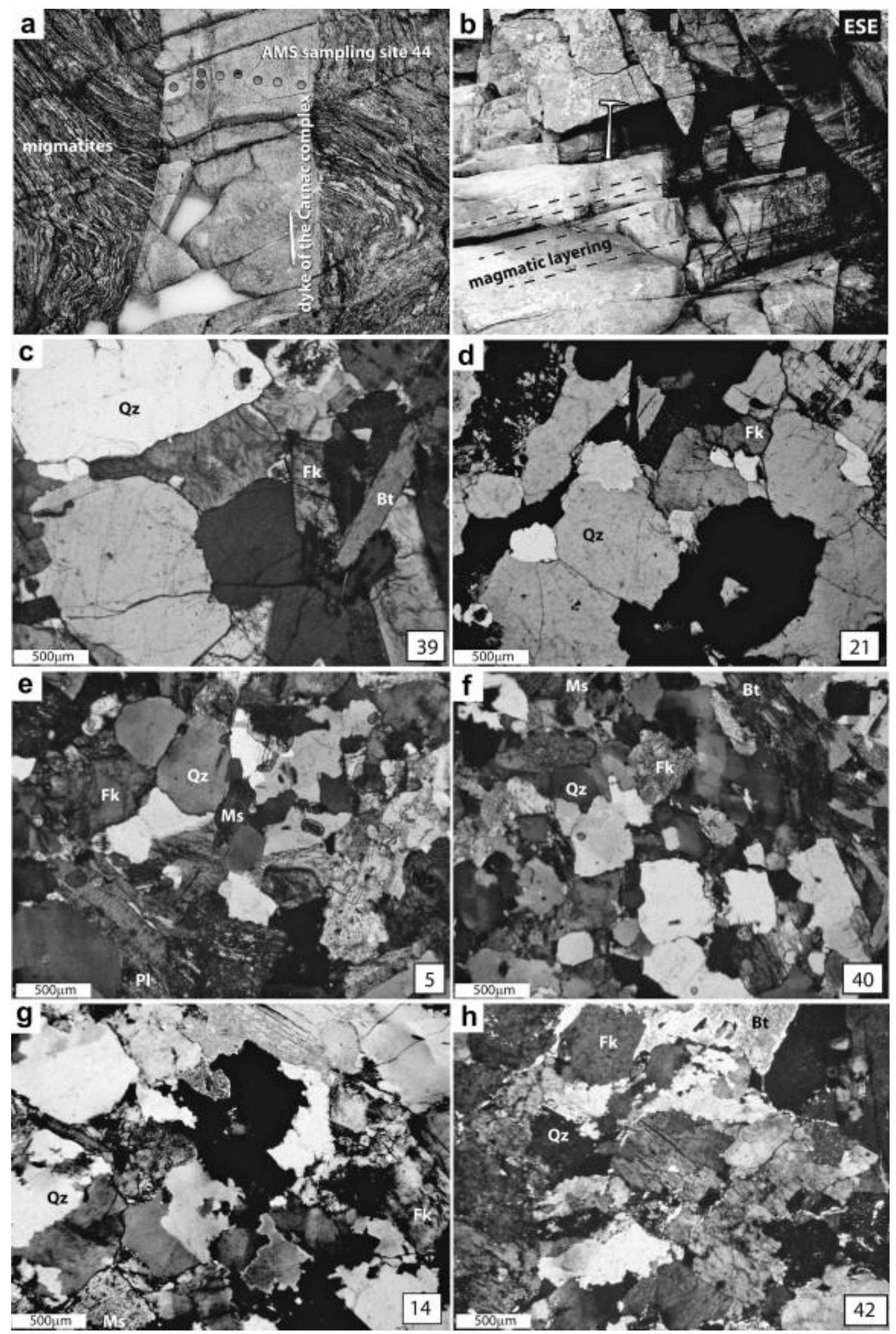
Fig. 2. : Outcrop pictures of representative dykes of the Carnac Complex, and microphotographs of the magmatic microstructures. On the right bottom of the thin section pictures $\mathrm{c}-\mathrm{h}$, the numbers refer to the sample name and to the AMS sites. Their location is given on Fig. 1. The thin sections are oriented parallel to the WNW-ESE stretching. Qz: quartz; Fk: K-feldspar; Pl: plagioclase; Bt: biotite; Ms: muscovite (a) Structural relationships between a steeply dipping $\mathrm{N} 30^{\circ} \mathrm{E}$ striking granitic dyke and its migmatitic host rock (vertical $\mathrm{N} 120^{\circ} \mathrm{E}$-striking foliation). Anatectic granite bodies belonging to the $\mathrm{S}^{\mathrm{te}}$-Anne d'Auray magmatic complex are intercalated within the migmatitic foliation. Note the sharp contact between the migmatites and the dyke; (b) Gently dipping dyke, with an internal fabric interpreted as magmatic layering; (c) and (d) Microstructures characteristic of undeformed granite; (e) and (f) Microstructures of moderate solid-state deformation; (g) and (h) Microstructure of significant solid-state deformation.

The Carnac Complex and the Quiberon leucogranitic pluton are ductilely deformed by the Sarzeau and the Quiberon shear zones. The Quiberon leucogranite emplacement is coeval with a top-to-the-WNW shearing along the W-dipping QSZ (Gapais et al., 1993), which has been dated between 310 and $300 \mathrm{Ma}$ (Ruffet in Le Hébel, 2002). East of the study area, the Carnac Complex is mylonitized within the gently eastward dipping SSZ, which is characterized by a top-to-the-ESE shearing (Turrillot et al., 2009; Fig. 1b). In the SSZ footwall, metre-scale shear bands with top-to-the-ESE sense of shear developed. The ductile shearing along the SSZ has been dated at 302-300 Ma by in-situ ${ }^{40} \mathrm{Ar} /{ }^{39} \mathrm{Ar}$ analyses on white mica neo-crystallizations along the shear planes (Turrillot, 2010). At the scale of the Morbihan area, it has been proposed that during a ductile WNW-ESE stretching, shearing with opposite kinematics along the QSZ and the SSZ allowed the exhumation of the Lower Unit in Late Carboniferous time (Turrillot et al., 2009).

During an overall cooling of the Lower Unit (Carpena, 1979), the deformation evolved into a brittle regime. Within the Lower and Intermediate units, numerous high-angle normal faults developed coeval with joints and tension gashes. Field evidence shows that these brittle structures crosscut the ductile ones. The inversion of fault slip data outlined a WNW-ESE extensional deformation during a late brittle regime that has been dated at 300-298 Ma by insitu ${ }^{40} \mathrm{Ar} /{ }^{39} \mathrm{Ar}$ analyses on white micas crystallized on the fault surfaces (Turrillot, 2010). These ages place the ductile-brittle transition at $300 \pm 2 \mathrm{Ma}$ and point to a $\sim 20 \mathrm{Ma}$ long-lived extensional deformation during the Upper Carboniferous times.

\subsection{The Carnac Complex}

\subsubsection{Overall framework and internal features}

The Carnac Complex consists of a granitic pluton developed to the west of the study area, which is surrounded by a pervasive granitic dyke swarm (Augier et al., in press). The geological map (Augier et al., in press) shows that the dyke swarm is more developed to the east, than to the west (Fig. 1b). The Carnac pluton consists mainly of homogeneous fine-tomedium grained biotite isotropic granite with rare cordierite. Locally, and particularly to the East, a two-mica facies can be observed. The dyke swarm is composed of a fine-grained biotite and muscovite facies similar to that of the Carnac pluton, but with a lower proportion of $\mathrm{Fe}-\mathrm{Mg}$ rich minerals (Augier et al., in press). 
The pluton and the dykes yield similar monazite $\mathrm{U}-\mathrm{Th} / \mathrm{Pb}$ ages, considering the analytic uncertainties (Turrillot et al., 2009). Yet, in the field, the relative timing based on intersecting structures between the pluton and its dyke swarm has never been clearly observed. The dyke thickness varies from $50 \mathrm{~cm}$ to more than $500 \mathrm{~m}$ (e.g. Ile aux Moines). Most of dykes are steeply (i.e. 90-60 ${ }^{\circ}$ ) west dipping, and rarely gently (i.e. 60-20 ${ }^{\circ}$ ) west dipping (Fig. 2a and b) as the average dip is ca. $82 \pm 8^{\circ}$. While most outcrops of the Carnac granite do not show any macroscopic magmatic fabric, some dykes exhibit a well-developed planar mineral preferred orientation defined by the alternation of quartz+feldspar-rich, and micas-rich layers lying parallel to the dyke walls (Fig. 2b). This penetrative fabric is interpreted here as a magmatic layering formed during the dyke emplacement. The dykes crosscut at right angle the migmatitic host-rocks fabric (Fig. 2a). A statistical measurement of the dyke walls orientation reveals a clear NNE-SSW regional trend (Turrillot, 2010), i.e. at right angle to the WNW-ESE maximum stretching inferred from the ductile deformation structures ( [Gapais et al., 1993] and [Turrillot et al., 2009] ). It has been proposed that the dykes of the Carnac Complex represent NNE-SSW striking large-scale tension gashes coeval with the WNW-ESE maximum stretching direction (Turrillot et al., 2009).

\subsubsection{Microstructure of the Carnac Complex}

In order to characterize the microstructure of the Carnac Complex, thin sections of apparently unstrained granite were made from the pluton and the dyke swarm. Sampling was done within the entire Carnac Complex and therefore tends to be representative of the whole massif. All thin sections were cut in the $\mathrm{X}-\mathrm{Z}$ plane, parallel to the direction of the WNW-ESE regional stretching. Representative examples of the Carnac granite microstructures are shown in Fig. 2, and the location of the corresponding sample is indicated in the geological map (Fig. 1b).

Three types of microstructures are distinguished. The first one shows anhedral, millimetrescale sized quartz grains with non-undulatory extinction and planar boundaries (e.g. samples 39 and 21). The quartz and feldspar grains do not show any crystal-plastic deformation or recrystallization evidence (Fig. 2c and d), or any particular mineral preferred orientation. These features are characteristic of undeformed granite (Paterson et al., 1989). The second type of microstructure displays $0.5-1 \mathrm{~mm}$ quartz grains (e.g. samples 5 and 40 ) with undulatory extinction. Some quartz grains are weakly recrystallized with a slight neograin formation (Fig. 2e and f). These features are characteristics of a moderate solid-state deformation (Paterson et al., 1989). The third type of granitic microstructure shows a significant solid-state deformation (Fig. $2 \mathrm{~g}$ and $\mathrm{h}$ ). Quartz grains with a noticeable grain-size reduction (smaller than $0.5 \mathrm{~mm}$ ), serrated boundaries, and undulatory extinction argue for a dynamic recrystallization process (e.g. samples 14 and 42).

Based on these microstructural observations at the scale of the entire Carnac Complex, supersolidus (i.e. magmatic) deformation and moderate solid-state deformation predominate in the pluton. Conversely, solid-state deformation predominates in the dykes of the Carnac Complex.

\section{Anisotropy of magnetic susceptibility (AMS) of the Carnac Complex}

The overall geometry of the Carnac Complex (i.e. the northern limit of the pluton and particularly its dyke swarm (Fig. 1b)) suggests that its emplacement occurred during a WNWESE stretching of the crust (Turrillot et al., 2009). At the outcrop scale, only rare evidence of linear mineral preferred orientation can be observed within gently dipping dykes, and except 
in the eastern part of the Carnac Complex (i.e. within the SSZ), the Carnac granite seems to be unstrained. Therefore, while the deformed zones have already been studied in detail by field structural means, an AMS survey was carried out on the entire Carnac Complex in order to identify systematically the planar and linear magnetic fabrics, and assess their geometric compatibility with an extensional tectonic setting during pluton emplacement as suggested by field observations. Furthermore, in order to understand the AMS fabrics displayed by related dykes of the Carnac Complex, a detailed AMS study was undertaken in two large dykes that crop out in the Golfe du Morbihan.

\subsection{AMS sampling}

The AMS survey of the Carnac Complex was performed on 46 sites comprising 343 oriented cores, drilled within the pluton and the dyke swarm. The poor exposure conditions within the pluton made an extensive sampling difficult. Nevertheless, the site distribution is homogeneous at the pluton scale, and provides a good coverage of the Carnac Complex, with an average of 1 site for $4 \mathrm{~km}^{2}$.

Excellent exposures along the seacoast of the Golfe du Morbihan allowed an additional specific AMS survey of 37 sites comprising 214 oriented cores through the Arradon and the Ile aux Moine dykes. AMS sites were spaced of several metres to $200 \mathrm{~m}$ depending on the outcrop conditions. Particular efforts were made to investigate the contact between the dykes and migmatitic host rocks. Therefore, the variation of the granite magnetic fabrics across the dykes has been studied taking into account the location of the sites with respect to the dyke borders.

\subsection{Measurements}

AMS and bulk magnetic susceptibility $(\mathrm{Km})$ were measured with an AGICO KLY-3S apparatus at the "Laboratoire de Magnétisme des roches d'Orléans" (CNRS-Université d'Orléans). For each site, the mean direction of the three principal axes of the AMS ellipsoid (K1 $\geq \mathrm{K} 2 \geq \mathrm{K} 3$ ) was computed with ANISOFT software using Jelinek statistics (Jelinek, 1981). ANISOFT software was also used to calculate the shape parameter $(T=2 \ln (\mathrm{K} 2 / \mathrm{K} 3) / \ln (\mathrm{K} 1 / \mathrm{K} 3)-1)$ and the anisotropy degree parameter $\left(\mathrm{P}_{\mathrm{j}}=\mathrm{K} 1 / \mathrm{K} 3\right)$ that together describes the AMS ellipsoid ( [Jelinek, 1978] , [Jelinek, 1981] and [Hrouda, 1982] ). Magnetic hysteresis curves were obtained using a translation inductometer within an electromagnet providing a field of up to 1 Tesla at the Paleomagnetic Laboratory of "Institut de Physique du Globe de Paris" (IPGP, Saint-Maur, France).

\subsection{Magnetic mineralogy}

The identification of the mineral phases that contribute to the magnetic signal is necessary in order to get meaningful geological significance on the measured magnetic fabric (e.g.

[Borradaile, 1988] , [Rochette et al., 1992] and [Borradaile and Henry, 1997] ). To do so, two methods of investigation were used: bulk magnetic susceptibility $(\mathrm{Km})$ and hysteresis curve. Fig. 3a presents the distribution of the bulk magnetic susceptibility deduced from the laboratory measurements of the 343 specimens of the Carnac Complex, and the 214 specimens drilled within the Arradon and Ile aux Moines dykes. Km measurements within the Carnac Complex present a unimodal distribution with weak values spreading around $85.3 \pm 48.0 \mu$ SI. Km measurement of the Arradon and Ile aux Moines dykes also provides a unimodal distribution around $46.3 \pm 22 \mu$ SI. These values $(<100 \mu \mathrm{SI})$ obtained for both 
surveys correspond to a typical Al-rich granite suggesting that paramagnetic phases (e.g. biotites) are the main contributor to AMS (Bouchez, 1997). Several specimens from the Carnac Complex show rather high Km values (>200 $\mu$ SI $-450 \mu$ SI) that could be explained by the presence of secondary mineralization hardly detected in the field and even in thin sections. These unusual high values, with respect to the majority of the Km measurements, are excluded from the discussion. Fig. $3 \mathrm{~b}$ and $\mathrm{c}$ show hysteresis curves of two samples, one from a site within the pluton, and one from a metre-scale dyke (see the sample locations in Fig. 1b). For these two samples, hysteresis curves show almost perfectly linear and reversible induced magnetic moment with increasing and decreasing magnetic field, characterising paramagnetic minerals as the principal carrier of magnetic susceptibility.

a

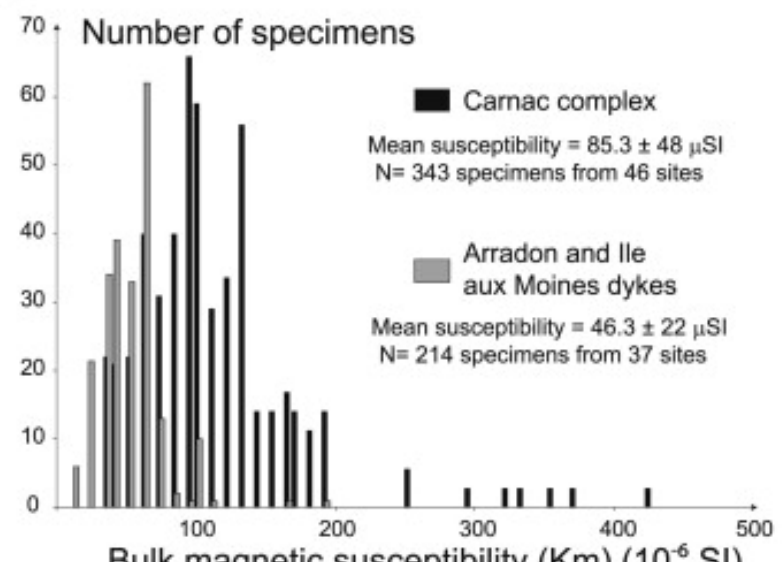

Bulk magnetic susceptibility $(\mathrm{Km})\left(10^{-6} \mathrm{SI}\right)$

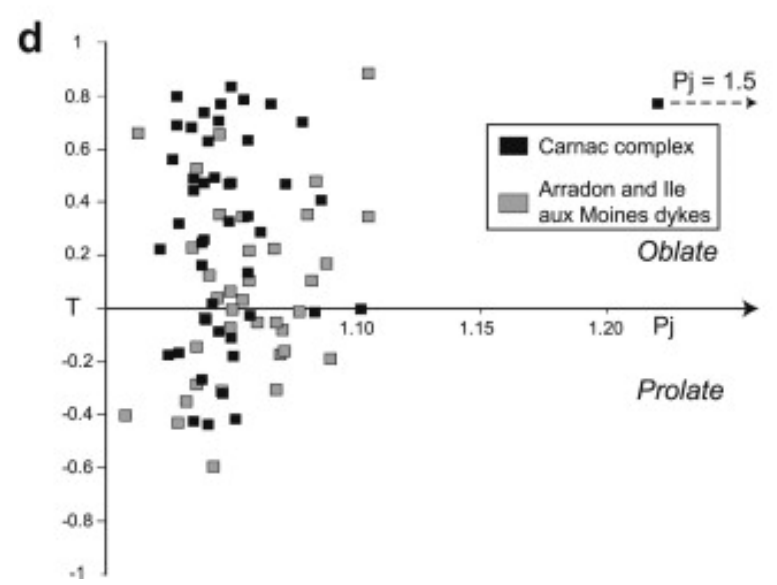

\section{b}

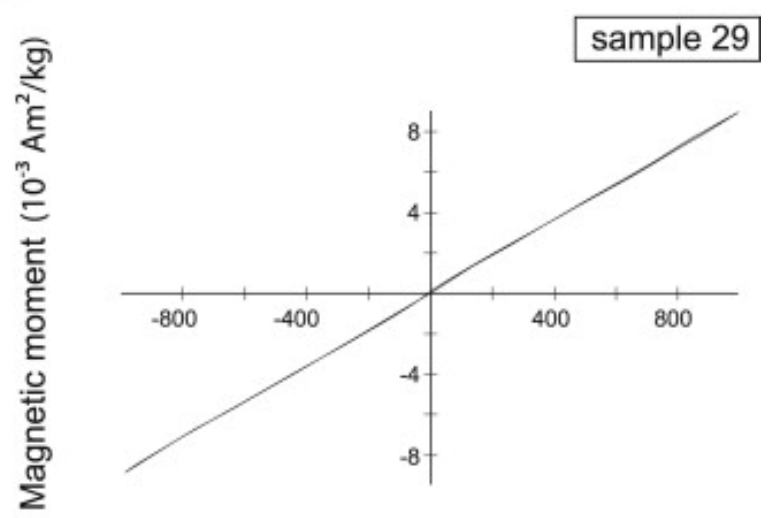

Applied magnetic field (mT)

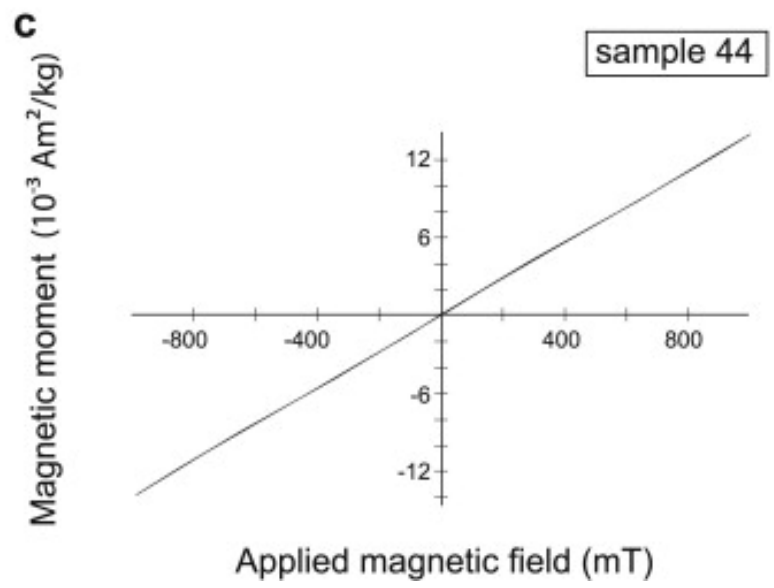

Fig. 3. : Information related to the magnetic mineralogy of the entire Carnac Complex and of the dykes. (a) Histogram of the bulk magnetic susceptibility measured from specimens of the Carnac Complex (black) and of the dykes of Ile aux Moines and Arradon (grey); (b) Hysteresis measurements of one specimen from the Carnac pluton (sample 29) (c) Hysteresis measurements of one specimen from a dyke (sample 44). The curves are characteristic of paramagnetic minerals showing linear relationships between the applied magnetic field and the magnetic moment; (d) AMS scalar parameters for each site. Anisotropy degree $\left(\mathrm{P}_{\mathrm{j}}\right) \mathrm{vs}$. shape parameter (T). AMS sites in the Carnac Complex are represented by black squares, and AMS sites in the Ile aux Moines and Arradon dykes are represented by grey squares. 
As described above, the magnetic mineralogy of the Carnac Complex is dominated by paramagnetic minerals such as micas, which are easily observed in the thin section (Fig. 2). The magnetic mineralogy is comparable between the Arradon and Iles aux Moine dykes. These analytic results are in agreement with the field observations of the Carnac Complex, where biotite may be considered as the main Fe-bearing mineral. Thus, the lower proportions of biotite in the dykes can be correlated to the corresponding lower $\mathrm{Km}$ values. As mentioned above in the mineralogical composition description, cordierite can be present in the Carnac Complex. In order to avoid the confusion in the interpretation of the magnetic fabric, the outcrops containing cordierite were carefully avoided during AMS sampling since this mineral is characterized by inverted $\mathrm{K} 1$ and $\mathrm{K} 3$ axes with respect to the micas (Rochette et al., 1992). Therefore, the magnetic signal can be mainly attributed to the biotite, and thus the K1 and $\mathrm{K} 3$ axes may be directly interpreted as the lineation and the pole of foliation of the mineral fabrics, respectively (Rochette et al., 1992).

\subsection{AMS results}

\subsubsection{Anisotropy degree and shape parameter}

The statistical results of the AMS measurements within the Carnac Complex and the Ile aux Moines and Arradon dykes are listed in Table 1. For each site, the mean declination, and inclination of the $\mathrm{K} 1$ and $\mathrm{K} 3$ axes with their corresponding confidence parameter $\left(\alpha_{95 \mathrm{~min}}\right)$, the average of $\mathrm{Km}$, and the $\mathrm{P}_{\mathrm{j}}$ and $\mathrm{T}$ parameters are provided. The plot of $\mathrm{P}_{\mathrm{j}} \mathrm{vs}$. T parameters is presented in Fig. 3d. Only one site (Site 24) shows a $P_{j}$ parameter $>1.5$ which may be influenced by a secondary mineralization or border effect as it is located near the contact with country rocks. The other sites are characterized by very weak values of $P_{j}(<1.102)$. In the $P_{j}$ vs. T diagram, the $\mathrm{T}$ parameter is scattered from -0.42 to 0.87 values for the Carnac Complex sites, and from -0.59 to 0.88 values for Arradon and Ile aux Moines dykes sites (Fig. 3d). This scattering does not reveal a dominance of planar (oblate) or linear (prolate) anisotropy within the measured sites. Moreover, no statistical reliable relationships between the $P_{j}$ and $T$ parameters can be established. 
Table 1. Results of AMS measurements from the Carnac Complex.

\begin{tabular}{|c|c|c|c|c|c|c|c|c|c|c|c|c|c|c|}
\hline \multirow[t]{2}{*}{ Site } & \multicolumn{2}{|c|}{ Coordinates } & \multirow[t]{2}{*}{$\mathbf{N}$} & \multicolumn{4}{|l|}{ K1 } & \multicolumn{4}{|l|}{ K3 } & \multirow[t]{2}{*}{ Km } & \multirow[t]{2}{*}{$\mathbf{P j}$} & \multirow[t]{2}{*}{$\mathbf{T}$} \\
\hline & Lat. $\left({ }^{\circ} \mathbf{N}\right)$ & Long. $\left({ }^{\circ} \mathbf{E}\right)$ & & $\operatorname{Dec}\left({ }^{\circ}\right)$ & $\operatorname{Inc}\left({ }^{\circ}\right)$ & $\alpha_{95} \min$ & $\alpha_{95} \max$ & $\operatorname{Dec}\left({ }^{\circ}\right)$ & $\operatorname{Inc}\left({ }^{\circ}\right)$ & $\alpha_{95} \mathrm{~min}$ & $\alpha_{95} \max$ & & & \\
\hline 1 & -2.9541 & 47.6387 & 7 & 130.6 & 18.5 & 3.3 & 8.5 & 25.3 & 38.3 & 4.8 & 9.8 & 91.0 & 1.049 & -0.111 \\
\hline 2 & -2.9160 & 47.6236 & 7 & 138.8 & 10.5 & 2.7 & 11.2 & 279.1 & 76.4 & 2.8 & 13.1 & 60.6 & 1.071 & 0.466 \\
\hline 3 & -2.8903 & 47.5827 & 7 & 308.6 & 43.3 & 6.6 & 9.5 & 132.1 & 46.6 & 4.2 & 13.8 & 96.5 & 1.042 & 0.489 \\
\hline 4 & -2.9175 & 47.5832 & 9 & 128.9 & 0.4 & 5.3 & 37.7 & 38.7 & 28.5 & 1.5 & 5.8 & 122.0 & 1.044 & 0.701 \\
\hline 5 & -2.9944 & 47.6411 & 7 & 195.3 & 15.6 & 3.2 & 7.6 & 320.9 & 64.3 & 6.6 & 8.5 & 66.2 & 1.039 & -0.046 \\
\hline 6 & -2.9730 & 47.6224 & 7 & 316.5 & 37.2 & 10.1 & 18.0 & 51.9 & 7.1 & 9.8 & 17.9 & 59.9 & 1.020 & 0.222 \\
\hline 7 & -2.9972 & 47.5982 & 7 & 323.0 & 56.9 & 1.0 & 2.6 & 99.0 & 25.1 & 0.9 & 7.1 & 103.0 & 1.056 & 0.132 \\
\hline 8 & -2.9506 & 47.5744 & 8 & 308.1 & 39.6 & 2.4 & 12.4 & 116.0 & 49.8 & 1.8 & 10.5 & 87.8 & 1.065 & 0.768 \\
\hline 9 & -2.9299 & 47.5555 & 8 & 244.1 & 27.7 & 6.1 & 28.8 & 103.9 & 55.6 & 6.0 & 7.1 & 80.8 & 1.038 & 0.733 \\
\hline 10 & -3.0049 & 47.5677 & 6 & 286.7 & 5.8 & 8.0 & 18.0 & 29.1 & 64.7 & 3.7 & 11.7 & 102.0 & 1.056 & 0.629 \\
\hline 11 & -3.0217 & 47.5910 & 6 & 207.4 & 54.4 & 1.9 & 6.4 & 302.1 & 3.4 & 5.9 & 18.3 & 106.0 & 1.051 & -0.418 \\
\hline 12 & -3.0543 & 47.5709 & 5 & 95.1 & 22.1 & 4.3 & 8.3 & 1.0 & 9.9 & 7.3 & 21.1 & 84.2 & 1.050 & -0.183 \\
\hline 13 & -3.0945 & 47.5650 & 7 & 283.2 & 58.9 & 3.5 & 5.3 & 62.3 & 24.5 & 4.6 & 10.2 & 56.1 & 1.040 & -0.440 \\
\hline 14 & -3.0491 & 47.5878 & 6 & 245.3 & 50.9 & 6.4 & 14.3 & 51.1 & 38.2 & 6.4 & 8.8 & 97.9 & 1.028 & 0.317 \\
\hline 15 & -3.0311 & 47.6056 & 10 & 284.9 & 41.4 & 3.4 & 9.7 & 106.1 & 48.6 & 5.4 & 11.0 & 81.1 & 1.041 & 0.017 \\
\hline 16 & -3.0682 & 47.6254 & 9 & 227.2 & 17.5 & 6.5 & 10.3 & 323.1 & 18.1 & 5.5 & 15.5 & 132.0 & 1.024 & -0.179 \\
\hline 17 & -3.0712 & 47.6010 & 11 & 233.1 & 59.8 & 11.9 & 24.8 & 42.6 & 29.8 & 7.4 & 19.9 & 95.8 & 1.033 & 0.680 \\
\hline 18 & -3.1286 & 47.5986 & 7 & 316.1 & 39.0 & 1.8 & 3.4 & 198.6 & 29.7 & 2.8 & 6.3 & 93.9 & 1.048 & 0.464 \\
\hline 19 & -3.1341 & 47.5431 & 8 & 309.1 & 49.7 & 4.9 & 8.4 & 99.7 & 36.4 & 4.7 & 8.6 & $\mid 171.0$ & 1.085 & 0.404 \\
\hline 20 & -3.1198 & 47.6285 & 9 & 234.1 & 47.6 & 5.0 & 8.0 & 68.0 & 41.6 & 4.2 & 5.8 & 61.4 & 1.034 & 0.487 \\
\hline 21 & -3.1597 & 47.6270 & 10 & 285.8 & 29.4 & 4.9 & 7.5 & 29.8 & 23.3 & 4.9 & 6.0 & 97.8 & 1.037 & 0.162 \\
\hline 22 & -3.1683 & 47.6117 & 6 & 207.3 & 71.4 & 2.8 & 7.9 & 88.5 & 9.2 & 5.1 & 18.0 & 106.0 & 1.046 & -0.321 \\
\hline 23 & -3.0821 & 47.6472 & 5 & 228.5 & 44.4 & 3.9 & 11.6 & 90.4 & 37.2 & 3.5 & 17.5 & 89.9 & 1.083 & -0.015 \\
\hline 24 & -3.1006 & 47.6625 & 10 & 293.9 & 32.7 & 5.2 & 23.9 & 98.1 & 56.3 & 3.4 & 8.3 & 265.0 & 1.515 & 0.779 \\
\hline 25 & -3.1010 & 47.6775 & 6 & 313.9 & 22.8 & 3.2 & 21.6 & 109.4 & 65.2 & 1.7 & 7.5 & 73.1 & 1.078 & 0.697 \\
\hline 26 & -3.1044 & 47.6972 & 5 & 263.1 & 2.9 & 0.9 & 4.4 & 170.3 & 44.4 & 1.2 & 10.4 & 34.5 & 1.028 & -0.169 \\
\hline 27 & -3.1421 & 47.6957 & 7 & 187.7 & 2.5 & 2.7 & 22.2 & 290.4 & 78.9 & 2.2 & 3.2 & 55.0 & 1.045 & 0.768 \\
\hline 28 & -3.1461 & 47.6625 & 7 & 334.6 & 13.1 & 2.5 & 11.2 & 102.1 & 69.0 & 2.2 & 4.7 & 86.4 & 1.056 & 0.345 \\
\hline 29 & -3.1610 & 47.6815 & 6 & 103.8 & 27.9 & 3.4 & 7.0 & 349.1 & 38.2 & 2.4 & 8.8 & 35.5 & 1.057 & -0.029 \\
\hline 30 & -3.1880 & 47.6824 & 7 & 302.7 & 42.0 & 3.7 & 19.2 & 84.0 & 40.9 & 3.8 & 7.6 & 148.0 & 1.049 & 0.832 \\
\hline 31 & -3.1986 & 47.6743 & 11 & 228.8 & 62.1 & 4.0 & 15.5 & 53.6 & 27.8 & 3.9 & 5.4 & 87.4 & 1.038 & 0.469 \\
\hline 32 & -3.1915 & 47.6605 & 6 & 312.5 & 67.4 & 6.7 & 10.3 & 104.1 & 20.2 & 3.6 & 13.8 & 88.6 & 1.034 & 0.442 \\
\hline 33 & -3.2073 & 47.6610 & 8 & 131.4 & 63.8 & 4.0 & 15.0 & 262.2 & 17.8 & 8.3 & 20.0 & 80.5 & 1.038 & 0.255 \\
\hline 34 & -3.2149 & 47.6450 & 5 & 330.6 & 72.3 & 6.1 & 13.1 & 227.4 & 4.1 & 4.6 & 12.7 & 38.3 & 1.049 & 0.470 \\
\hline 35 & -3.2134 & 47.6929 & 5 & 22.9 & 21.3 & 7.8 & 48.1 & 223.9 & 67.3 & 4.4 & 13.7 & 17.0 & 1.027 & 0.686 \\
\hline 36 & -3.2648 & 47.6854 & 9 & 327.2 & 53.6 & 5.9 & 7.0 & 143.6 & 36.4 & 2.7 & 8.7 & 77.1 & 1.037 & -0.269 \\
\hline 37 & -3.2423 & 47.7307 & 5 & 265.1 & 50.0 & 11.2 & 16.7 & 93.5 & 39.7 & 2.3 & 12.2 & 80.9 & 1.040 & 0.626 \\
\hline 38 & -3.2254 & 47.7105 & 7 & 269.6 & 34.0 & 1.9 & 5.5 & 90.2 & 56.0 & 1.9 & 9.9 & 69.9 & 1.037 & 0.246 \\
\hline 39 & -3.2134 & 47.7073 & 6 & 336.4 & 14.2 & 2.1 & 26.5 & 76.6 & 34.8 & 4.7 & 9.8 & 164.0 & 1.054 & 0.785 \\
\hline 40 & -3.0422 & 47.6859 & 10 & 284.5 & 21.5 & 2.5 & 8.9 & 121.2 & 67.7 & 2.1 & 5.3 & 48.5 & 1.061 & 0.286 \\
\hline 41 & -2.8305 & 47.6144 & 17 & 356.7 & 35.0 & 9.0 & 42.1 & 108.5 & 27.9 & 8.9 & 12.1 & 25.3 & 1.031 & 0.873 \\
\hline 43 & -2.9151 & 47.5460 & 7 & 243.4 & 47.4 & 5.5 & 9.4 & 86.0 & 40.3 & 5.6 & 13.0 & 44.5 & 1.048 & 0.325 \\
\hline
\end{tabular}




\begin{tabular}{|c|c|c|c|c|c|c|c|c|c|c|c|c|c|c|}
\hline \multirow[t]{2}{*}{ Site } & \multicolumn{2}{|c|}{ Coordinates } & \multirow[t]{2}{*}{$\mathbf{N}$} & \multicolumn{4}{|l|}{ K1 } & \multicolumn{4}{|l|}{ K3 } & \multirow[t]{2}{*}{$\mathbf{K m}$} & \multirow[t]{2}{*}{$\mathbf{P j}$} & \multirow[t]{2}{*}{$\mathbf{T}$} \\
\hline & Lat. $\left({ }^{\circ} \mathbf{N}\right)$ & Long. $\left({ }^{\circ} \mathbf{E}\right)$ & & $\operatorname{Dec}\left({ }^{\circ}\right)$ & $\operatorname{Inc}\left({ }^{\circ}\right)$ & $\alpha_{95} \min$ & $\alpha_{95} \max$ & $\operatorname{Dec}\left({ }^{\circ}\right)$ & $\operatorname{Inc}\left({ }^{\circ}\right)$ & $\alpha_{95} \mathrm{~min}$ & $\alpha_{95} \max$ & & & \\
\hline 44 & -2.9160 & 47.5460 & 5 & 4.1 & 61.6 & 3.9 & 52.9 & 105.6 & 6.1 & 4.8 & 17.3 & 43.4 & 1.025 & 0.560 \\
\hline 45 & -2.9138 & 47.5569 & 8 & 207.2 & 44.9 & 3.2 & 4.3 & 50.5 & 42.7 & 3.2 & 4.3 & 106.0 & 1.044 & -0.090 \\
\hline IS19 & -2.8539 & 47.6003 & 8 & 306.9 & 7.1 & 19.7 & 25.7 & 202.0 & 64.1 & 22.6 & 62.0 & 18.4 & 1.034 & -0.427 \\
\hline PS20 & -2.8619 & 47.6183 & 6 & 308.1 & 6.5 & 2.3 & 5.6 & 205.5 & 62.4 & 4.1 & 4.9 & 91.9 & 1.101 & -0.004 \\
\hline
\end{tabular}

Lat.: Latitude, Long.: Longitude; N: number of specimens; Dec, Inc, $\alpha_{95} \mathrm{~min}, \alpha_{95} \mathrm{max}$ are declination, inclination, Jelinek's statistic confidence at 95\% level (Jelinek, 1981) in degrees, respectively; Km: Meanbulk magnetic susceptibility, Pj: Corrected anisotropy degree, and T: Anisotropy shape parameter (Jelinek, 1981).

\subsubsection{AMS fabric patterns of the Carnac Complex}

Fig. 4 shows the spatial distribution of the AMS sites within the Carnac Complex and the results of magnetic fabric from the AMS measurements. The magnetic lineation (K1) and the pole of the magnetic foliation (K3) are plotted on an equal-area and lower hemispheric projection. Most of the sites show well-grouped K1 and K3 axes projection. This observation is also confirmed by low values of confidence circles $\left(\alpha_{95 \mathrm{~min}}\right)$ for the magnetic lineation and for the pole of magnetic foliation, as well (Table 1). Though an overall westward dipping attitude can be noticed, the poles of the magnetic foliation show rather variable directions (Fig. 5a). The magnetic lineation is arranged along two mean directions (Fig. 5b), and globally shows a westward plunge. The main lineation direction trends WNW-ESE, parallel to the one inferred from the ductile and brittle structures ( [Turrillot et al., 2009] and [74] ), and presents variable plunges decreasing eastward from more than $60^{\circ}$ to less than $10^{\circ}$ (see dip variations in WNW-ESE direction in Fig. 5b). The second cluster of the magnetic lineation direction is oriented NNE-SSW, that is parallel to the average dyke orientation, and plunges are mainly grouped around $40^{\circ}$ (Fig. 5b). 


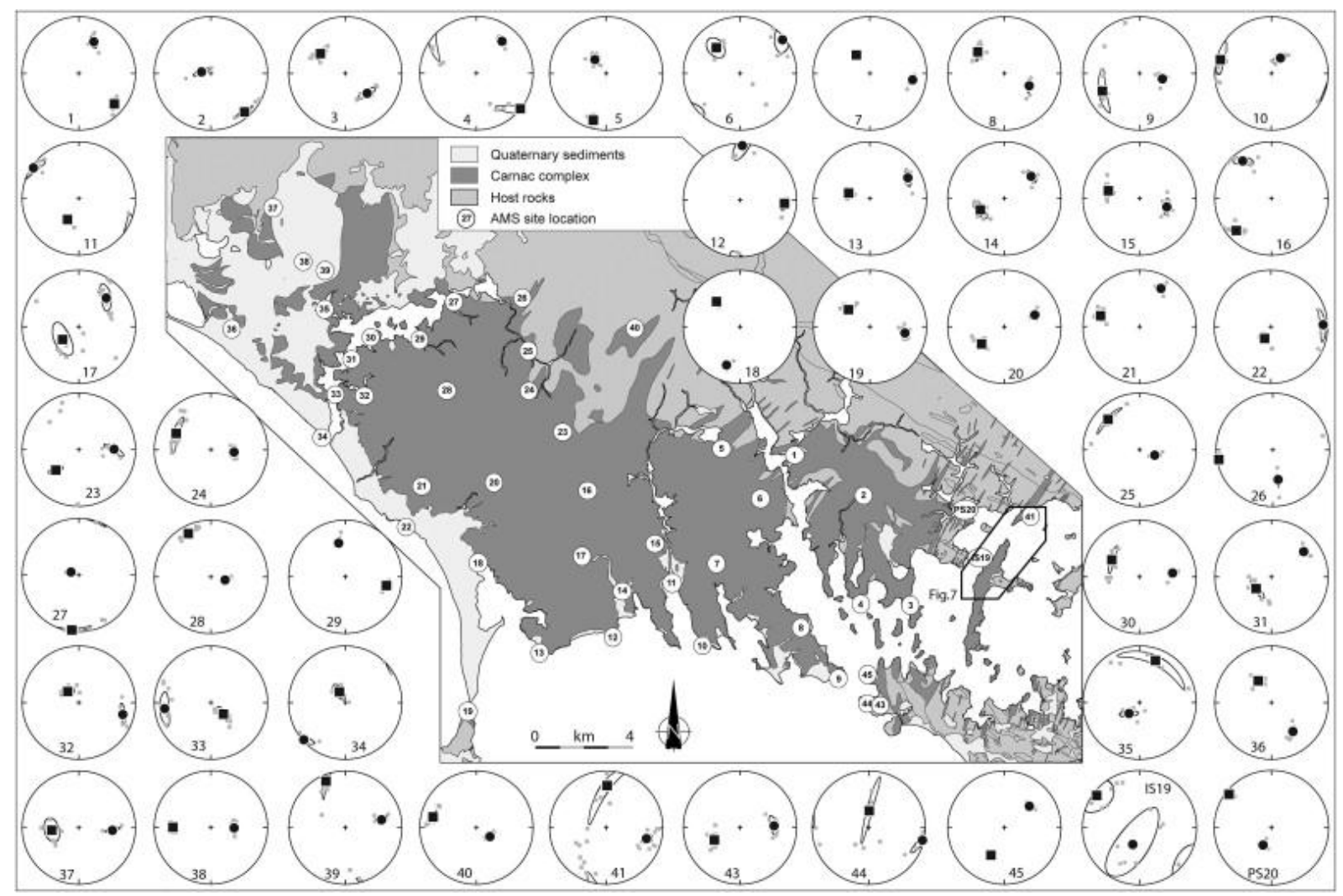

Fig. 4. : Equal area projection (lower hemisphere) of the AMS results for each site within the Carnac Complex. On the map, the white circled numbers refer to the AMS sites. On the stereoplots, squares and circles are K1 (magnetic lineation) and K3 (pole of magnetic foliation), respectively. Small grey dots and large black ones represent individual specimens and site-mean direction, respectively. Confidence ellipses at 95\% level are drawn around average orientation direction. 

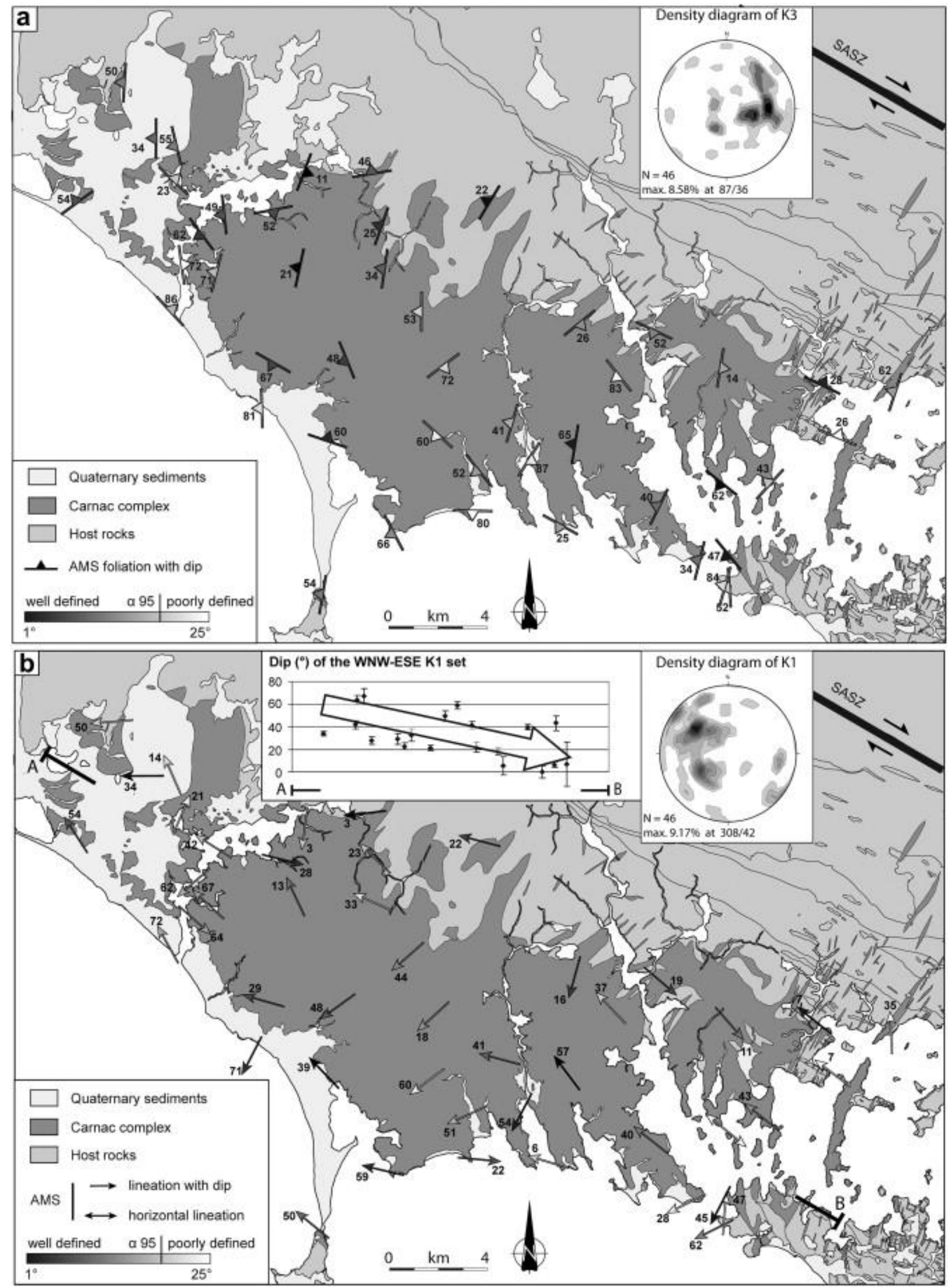

Fig. 5. : Magnetic fabric maps of the Carnac Complex. Information on confidence parameter $\left(\alpha_{95} \mathrm{~min}\right)$ is given for each magnetic fabric. Equal-area projections (lower hemisphere) show the density contours of individual AMS foliation and AMS lineation. (a) Magnetic foliation; 
(b) Magnetic lineation. For the WNW-ESE oriented K1 axes, dip variation is given along the A-B section.

\subsubsection{AMS fabric patterns of the Arradon and Ile aux Moines dykes}

The distribution of the AMS fabrics along transects through the Arradon and Ile aux Moines dykes are depicted in Fig. 6. Most of the sites show low values of the confidence parameter $\left(\alpha_{95} \mathrm{~min}\right)$ for both the magnetic lineation and pole of magnetic foliation, comparable to those obtained from the Carnac Complex (Table 2). The measured direction of magnetic lineation for all the sites is consistent. The magnetic foliation shows a rather horizontal attitude with various strikes that can be related to their general shallow dip. The magnetic lineation is globally horizontal and clusters around a well-defined WNW-ESE direction. However, some sites on the margins of the dykes may suffer a local thermal or mechanical perturbation magnetic lineation and show ENE-SSW orientations (see Sites IS17, 22E2 or AS13 in Fig. 6), i.e. parallel to the general dyke orientation (Fig. 1; Turrillot, 2010). 


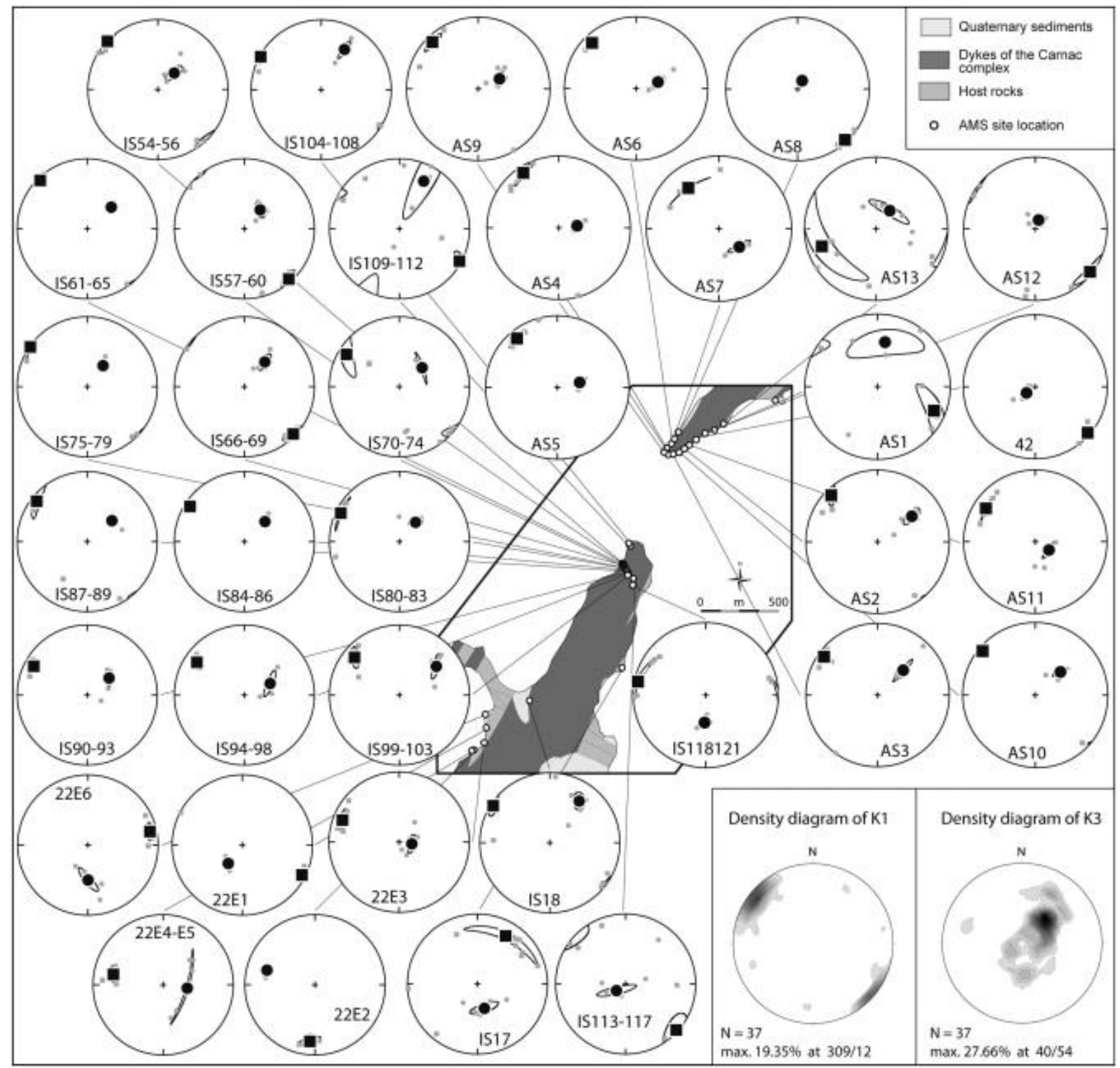

Fig. 6. : Equal area projection (lower hemisphere) of the AMS results for each site within the Ile aux Moines and Arradon dykes. AMS site locations within the Ile aux Moines and Arradon dykes are given by small white circles on the map. On the stereoplots, squares and circles are K1 (magnetic lineation) and K3 (pole of magnetic foliation), respectively. Small grey dots and larger black ones represent individual specimen and site-mean direction, respectively. Confidence ellipses at 95\% level are drawn around average orientation direction. In the bottom-right corner equal-area projections (lower hemisphere) show the density contours of individual AMS foliation and AMS lineation. 
Table 2. Results of AMS measurements from the Arradon and Ile aux Moines dykes.

\begin{tabular}{|c|c|c|c|c|c|c|c|c|c|c|c|c|c|c|}
\hline \multirow[t]{2}{*}{ Site } & \multicolumn{2}{|c|}{ Coordinates } & \multirow[t]{2}{*}{$\mathbf{N}$} & \multicolumn{4}{|l|}{ K1 } & \multicolumn{4}{|l|}{ K3 } & \multirow[t]{2}{*}{ BMS } & \multirow[t]{2}{*}{$\mathbf{P}$} & \multirow[t]{2}{*}{$\mathbf{T}$} \\
\hline & Lat. $\left({ }^{\circ} \mathbf{N}\right)$ & Long. $\left({ }^{\circ} \mathbf{E}\right)$ & & $\operatorname{Dec}\left({ }^{\circ}\right)$ & $\operatorname{Inc}\left({ }^{\circ}\right)$ & $\alpha_{95} \min$ & $\alpha_{95} \max$ & $\operatorname{Dec}\left({ }^{\circ}\right)$ & $\operatorname{Inc}\left({ }^{\circ}\right)$ & $\alpha_{95} \mathrm{~min}$ & $\alpha_{95} \max$ & & & \\
\hline 42 & -2.8323 & 47.6143 & 6 & 131.5 & 4.2 & 2.7 & 6.1 & 241.4 & 77.8 & 2.8 & 8.0 & 38.2 & 1.035 & -0.286 \\
\hline AS1 & -2.8339 & 47.6131 & 4 & 113.0 & 16.8 & 8.7 & 35.7 & 9.5 & 37.8 & 15.7 & 41.1 & 55.3 & 1.006 & -0.403 \\
\hline AS2 & -2.8347 & 47.6128 & 7 & 315.2 & 9.4 & 3.9 & 12.5 & 53.3 & 40.2 & 4.2 & 13.7 & 45.9 & 1.036 & -0.145 \\
\hline AS3 & -2.8353 & 47.6128 & 6 & 305.6 & 9.0 & 3.6 & 5.7 & 46.0 & 48.8 & 2.1 & 18.0 & 26.7 & 1.026 & -0.429 \\
\hline AS4 & -2.8358 & 47.6128 & 7 & 327.2 & 9.7 & 3.1 & 14.8 & 83.6 & 69.0 & 4.2 & 6.7 & 31.0 & 1.054 & 0.344 \\
\hline AS5 & -2.8356 & 47.6131 & 6 & 320.5 & 12.4 & 3.9 & 10.5 & 77.1 & 63.9 & 4.0 & 4.1 & 36.0 & 1.040 & 0.123 \\
\hline AS6 & -2.8356 & 47.6131 & 6 & 316.1 & 12.6 & 2.6 & 5.6 & 73.4 & 64.0 & 2.7 & 9.3 & 33.3 & 1.048 & 0.062 \\
\hline AS7 & -2.8350 & 47.6133 & 3 & 323.1 & 30.4 & 0.3 & 24.1 & 131.9 & 51.1 & 3.0 & 13.7 & 28.1 & 1.044 & 0.655 \\
\hline AS8 & -2.8347 & 47.6139 & 6 & 136.9 & 3.4 & 1.9 & 6.9 & 28.9 & 79.1 & 1.9 & 4.5 & 44.5 & 1.080 & 0.352 \\
\hline AS9 & -2.8356 & 47.6131 & 7 & 315.6 & 9.4 & 3.8 & 10.5 & 64.8 & 63.1 & 4.3 & 9.0 & 30.3 & 1.059 & -0.054 \\
\hline AS10 & -2.8350 & 47.6128 & 4 & 309.8 & 6.2 & 2.2 & 8.1 & 47.5 & 51.1 & 2.8 & 10.2 & 30.0 & 1.045 & -0.311 \\
\hline AS11 & -2.8342 & 47.6128 & 6 & 304.0 & 18.1 & 1.3 & 12.0 & 121.3 & 71.8 & 2.3 & 11.9 & 50.4 & 1.043 & 0.040 \\
\hline AS12 & -2.8336 & 47.6133 & 7 & 128.2 & 3.2 & 5.7 & 17.5 & 20.9 & 79.2 & 3.7 & 7.5 & 23.4 & 1.033 & 0.228 \\
\hline AS13 & -2.8314 & 47.6142 & 6 & 252.1 & 21.6 & 13.1 & 57.0 & 37.0 & 64.1 & 5.4 & 25.7 & 31.9 & 1.011 & 0.657 \\
\hline IS54-56 & -2.8389 & 47.6061 & 6 & 313.8 & 0.4 & 5.5 & 11.8 & 44.6 & 62.8 & 5.1 & 12.1 & 38.0 & 1.056 & 0.106 \\
\hline IS57-60 & -2.8389 & 47.6061 & 5 & 138.6 & 4.7 & 6.4 & 9.4 & 39.9 & 61.2 & 5.9 & 9.4 & 37.7 & 1.056 & 0.218 \\
\hline IS61-65 & -2.8389 & 47.6060 & 5 & 317.3 & 0.6 & 0.7 & 5.9 & 48.0 & 51.9 & 1.4 & 4.6 & 50.0 & 1.069 & -0.081 \\
\hline IS66-69 & -2.8389 & 47.6058 & 5 & 134.1 & 3.5 & 4.2 & 11.0 & 39.5 & 52.1 & 4.3 & 11.8 & 54.3 & 1.067 & -0.054 \\
\hline IS70-74 & -2.8388 & 47.6058 & 6 & 301.4 & 12.6 & 7.0 & 28.7 & 50.1 & 55.1 & 1.8 & 19.2 & 56.3 & 1.068 & -0.174 \\
\hline IS75-79 & -2.8388 & 47.6058 & 5 & 305.1 & 1.0 & 0.5 & 12.6 & 36.8 & 59.1 & 1.3 & 5.2 & 56.4 & 1.104 & 0.347 \\
\hline IS $80-83$ & -2.8387 & 47.6058 & 6 & 296.0 & 7.7 & 1.6 & 16.4 & 39.9 & 60.5 & 2.4 & 8.7 & 61.3 & 1.087 & 0.167 \\
\hline IS84-86 & -2.8387 & 47.6072 & 5 & 303.0 & 8.4 & 0.9 & 3.1 & 45.8 & 56.2 & 0.9 & 5.8 & 52.6 & 1.081 & 0.105 \\
\hline IS87-89 & -2.8387 & 47.6057 & 6 & 308.8 & 8.5 & 4.4 & 18.1 & 49.7 & 51.8 & 2.5 & 4.6 & 52.7 & 1.083 & 0.478 \\
\hline IS90-93 & -2.8386 & 47.6056 & 6 & 298.4 & 14.4 & 3.1 & 6.8 & 52.2 & 57.5 & 2.9 & 9.3 & 53.9 & 1.076 & -0.013 \\
\hline IS94-98 & -2.8383 & 47.6056 & 5 & 304.6 & 18.7 & 3.2 & 7.1 & 66.0 & 56.9 & 3.7 & 16.3 & 55.6 & 1.070 & -0.163 \\
\hline IS99-103 & -2.8383 & 47.6058 & 5 & 310.0 & 17.6 & 3.9 & 13.5 & 52.2 & 33.7 & 3.3 & 15.8 & 53.7 & 1.067 & -0.305 \\
\hline IS104-108 & -2.8389 & 47.6075 & 5 & 298.8 & 1.7 & 2.0 & 7.2 & 29.9 & 33.9 & 2.6 & 13.9 & 54.0 & 1.089 & -0.191 \\
\hline IS109-112 & -2.8388 & 47.6075 & 5 & 118.3 & 2.8 & 4.5 & 13.9 & 27.0 & 24.6 & 10.2 & 53.0 & 28.5 & 1.041 & -0.594 \\
\hline IS113-117 & -2.8383 & 47.6050 & 5 & 132.2 & 2.7 & 12.7 & 17.4 & 234.0 & 76.9 & 4.1 & 23.8 & 46.4 & 1.038 & -0.038 \\
\hline IS118-121 & -2.8381 & 47.6044 & 7 & 281.3 & 5.2 & 2.5 & 26.7 & 182.6 & 59.0 & 2.8 & 6.2 & 51.9 & 1.044 & 0.354 \\
\hline IS17 & -2.8397 & 47.5997 & 11 & 30.4 & 21.4 & 5.4 & 41.0 & 164.1 & 60.4 & 5.0 & 16.9 & 111.0 & 1.104 & 0.882 \\
\hline IS18 & -2.8475 & 47.5983 & 9 & 303.2 & 3.8 & 6.0 & 10.1 & 35.2 & 27.9 & 6.4 & 11.2 & 40.9 & 1.053 & 0.031 \\
\hline 22-E1 & -2.8527 & 47.5954 & 5 & 116.6 & 5.4 & 4.2 & 5.2 & 217.4 & 63.0 & 1.6 & 7.3 & 35.5 & 1.067 & 0.223 \\
\hline $22-\mathrm{E} 2$ & -2.8527 & 47.5954 & 3 & 185.1 & 20.2 & 4.0 & 11.6 & 287.0 & 29.2 & 0.9 & 6.8 & 34.4 & 1.035 & 0.525 \\
\hline $22-\mathrm{E} 3$ & -2.8521 & 47.5957 & 7 & 291.3 & 14.5 & 3.6 & 10.8 & 97.9 & 75.1 & 4.3 & 10.9 & 54.6 & 1.048 & -0.071 \\
\hline 22-E4E5 & -2.8521 & 47.5963 & 5 & 281.8 & 28.3 & 4.8 & 8.8 & 98.0 & 61.7 & 1.4 & 45.6 & 86.3 & 1.031 & -0.352 \\
\hline 22-E6 & -2.8523 & 47.5970 & 6 & 77.7 & 10.4 & 3.8 & 8.2 & 179.7 & 48.7 & 4.1 & 17.7 & 40.9 & 1.049 & -0.006 \\
\hline
\end{tabular}

Lat.: Latitude, Long.: Longitude; N: number of specimens; Dec, Inc, $\alpha_{95} \min , \alpha_{95} \max$ are declination, inclination, Jelinek's statistic confidence at 95\% level (Jelinek, 1981) in degrees, respectively; Km: Meanbulk magnetic susceptibility, Pj: Corrected anisotropy degree, and T: Anisotropy shape parameter (Jelinek, 1981). 
Fig. 7 is a cross-sectional view of the Arradon and Ile aux Moines dykes. Positions of the AMS sites are projected on the plane of section. Along the cross sections, the variations of K1 in declination and inclination, as well as the variation of anisotropy degree and shape parameter are presented. The $\mathrm{K} 1$ declination trends around $\mathrm{N} 130{ }^{\circ} \mathrm{E}$ within the dykes and derive near the dyke walls. The $\mathrm{K} 1$ inclination is clustered around $10^{\circ}$ within the dykes and become scattered from $5^{\circ}$ to $30^{\circ}$ towards the border (from $\sim 20 \mathrm{~m}$ to the border). The anisotropy degree is not spatially organized across the dykes, and varies from 1.01 to 1.101. A particular attention has to be paid to the variations of the shape parameter, especially along the Arradon dyke. The magnetic ellipsoid is prolate $(T<0)$ in the central part of the dyke and becomes oblate $(T>0)$ towards the borders (Fig. 7), where the magnetic fabrics is therefore in agreement with the planar mineral preferred orientations (Fig. 2b). This spatial organisation of the shape parameter is not so clearly depicted by in the Ile aux Moines dyke (Fig. 7). 


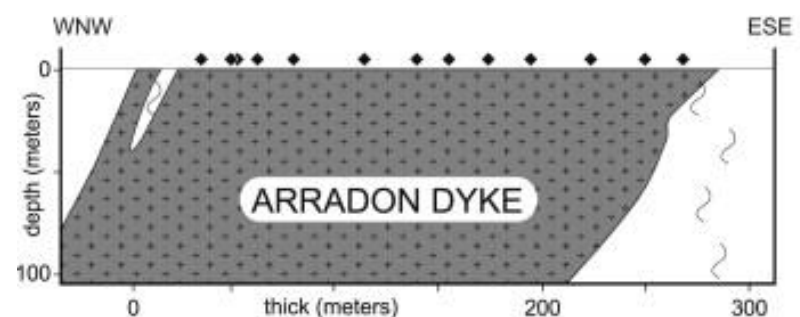

Carnac granite

Migmatites (ViseanNamurian)
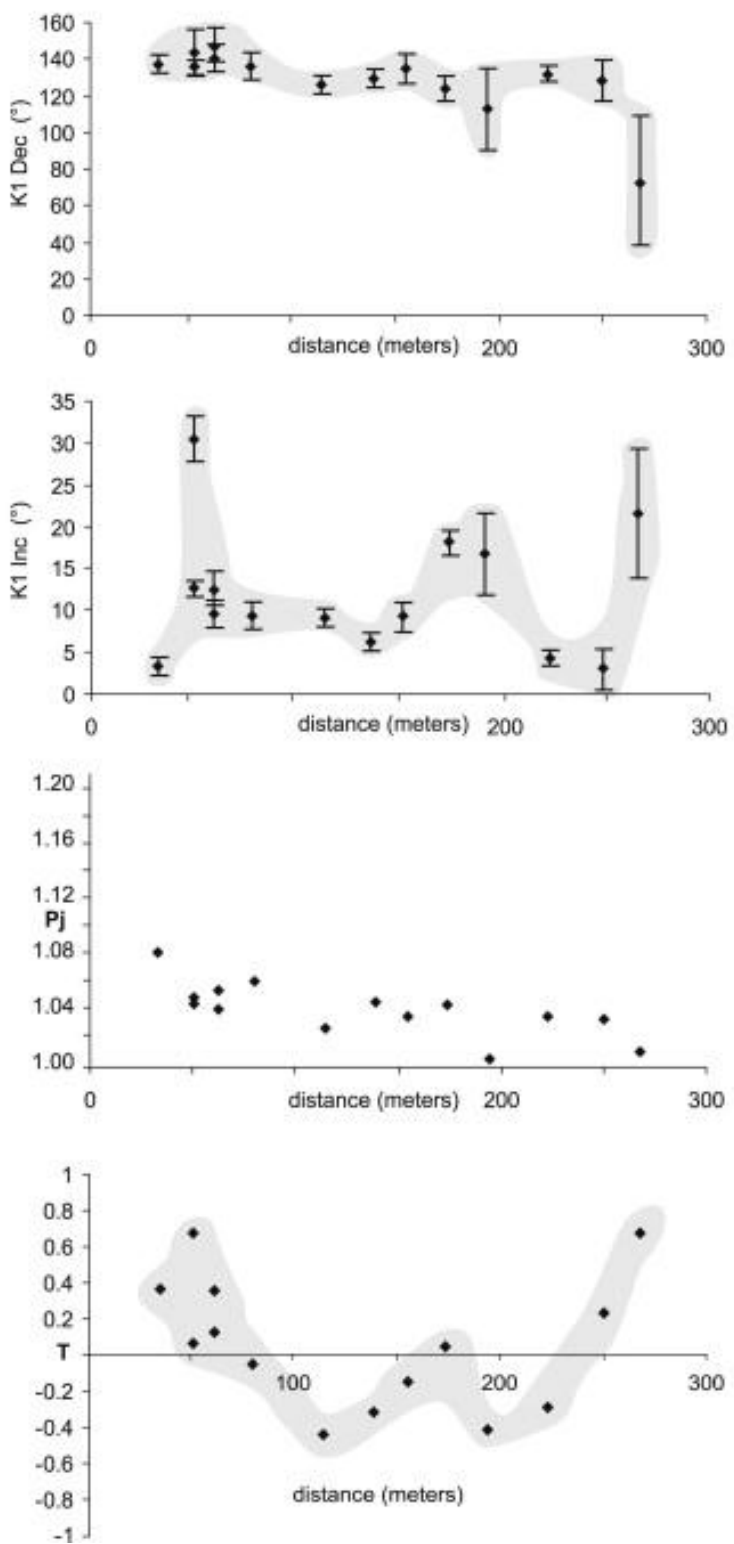

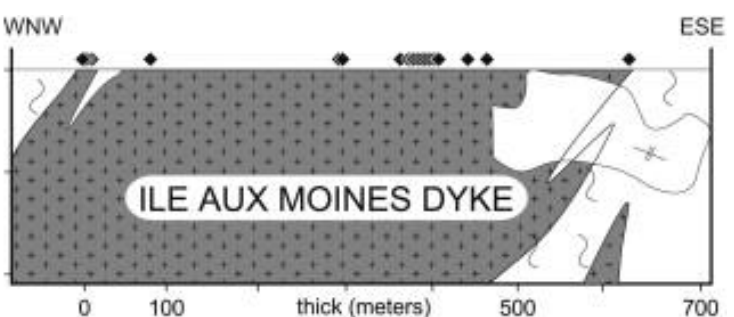

Pre-Hercynian $\mathcal{*}$ Attitude of Orthogneiss granite (Ordovician) $\sim$ and Migmatite foliation
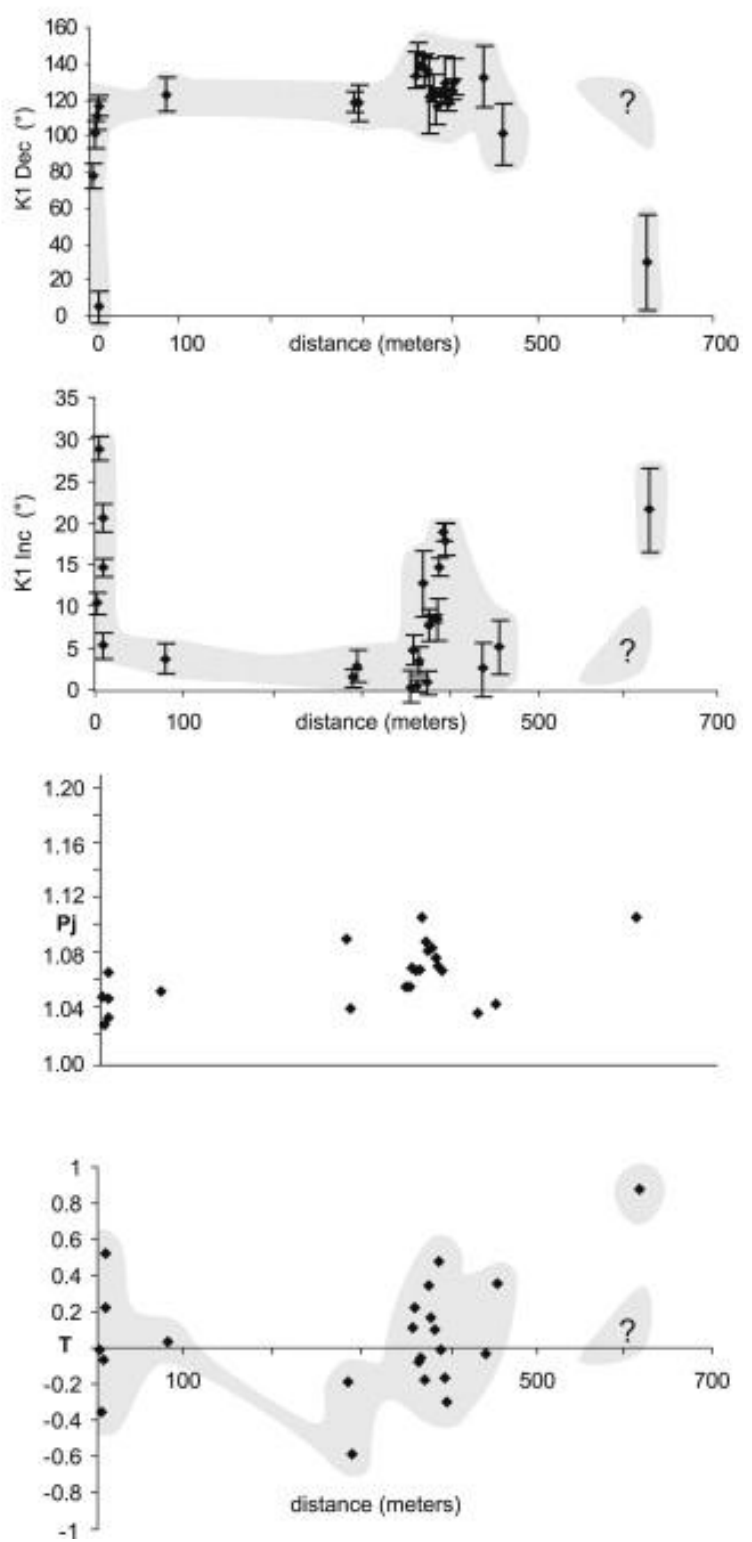

Fig. 7. : Cross sections through the Arradon and the Ile aux Moines dykes showing the variations of $\mathrm{K} 1$ declination $\left({ }^{\circ}\right), \mathrm{K} 1$ inclination $\left({ }^{\circ}\right)$, anisotropy degree $\left(\mathrm{P}_{\mathrm{j}}\right)$ and shape parameter $(\mathrm{T})$ across the dykes. Black dots are AMS sites projected on the cross-sections with respect to their distance to the border of the dykes. On the diagrams, the grey surfaces represent the mean variation of the different parameters. The errors bars correspond to the confidence parameter $\left(\alpha_{95 \mathrm{~min}}\right)$. 


\section{Gravity study of the Carnac Complex}

In order to constrain the shape and possible feeder zones of the Carnac pluton, the geometry of the dykes, and the structural relationships between the pluton and the dyke swarm, we carried out a gravity study. The gravity coverage of the Morbihan area available from the "Banque Gravimétrique de la France" was not sufficient to perform a detailed gravity modelling with respect to the complicated cartographic shape of the Carnac Complex. Therefore, 243 new gravity stations have been surveyed, leading to an average coverage of one gravity measurement per square kilometre on an area enclosing the Carnac Complex within 3-4 km of surrounding host rocks. The station locations are displayed on Fig. 8d. The gravity measurements were concentrated to the west of the Golfe du Morbihan, where the pluton and the dyke swarm of the Carnac Complex are both well developed. In addition, a high-resolution gravity transect was measured across the Ile aux Moines dyke and surrounding migmatites, perpendicularly to its NNE-SSW direction. Along the transect, gravity stations were located every $200 \mathrm{~m}$, with a higher resolution of 1 station every $100 \mathrm{~m}$ at the narrowest part and within the dyke (Fig. 8d). 

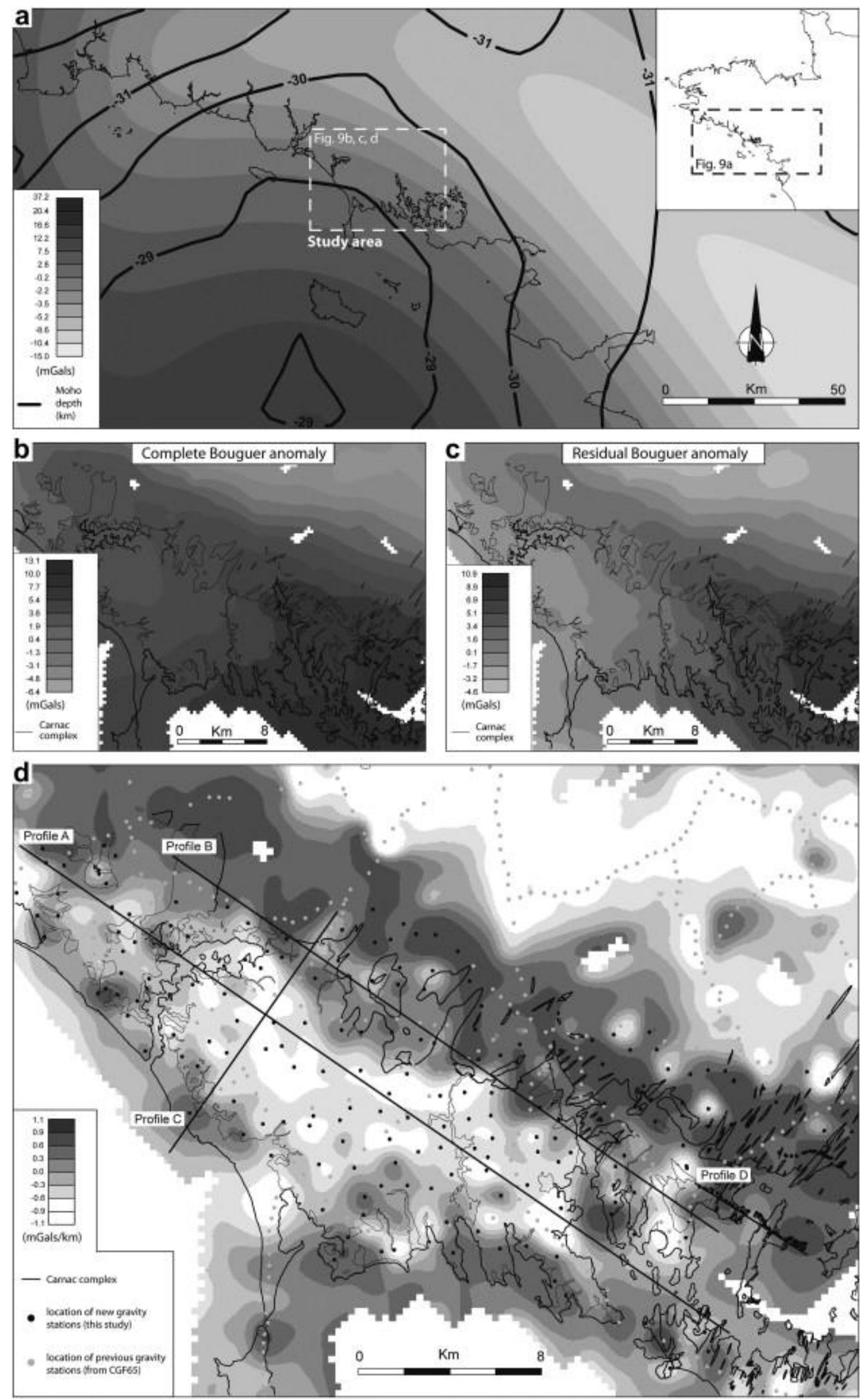

Fig. 8. : Main results of the gravity survey. (a) In grey levels, the regional Bouguer anomaly, compared to the regional Moho undulations (black thick lines); (b) Complete Bouguer 
anomaly of the study area resulting from the combination of our new gravity data and the available gravity data from the BGF French gravity database; (c) resulting residual Bouguer anomaly, mostly influenced by the density heterogeneities located in the first kilometres below the topography. Given are the profile locations of Fig. 9. Black dots correspond to our gravity measurements, grey dots come from the BGF.

\subsection{Gravity data acquisition and positioning}

Measurements were collected using a Scintrex CG3-M microgravimeter previously calibrated at the "Bureau International des Poids et des Mesures" (BIPM). In the field, the measurements were tied to the CGF 65 French gravity base network. For the gravity stations measured in the pluton, the stations were positioned on IGN geodesic benchmarks, with a vertical accuracy better than $1 \mathrm{~m}$. For the gravity transect across the Ile aux Moines dyke, the stations were positioned using differential GPS, with a vertical accuracy better than $0.5 \mathrm{~m}$.

The gravity anomaly was reduced to the Hayford-1930 ellipsoid. The complete Bouguer anomaly was obtained after successively performing the free air, plateau and terrain corrections. A Bouguer reduction density of 2.6 (i.e. close to a typical granite density) was used. On the field, inner terrain corrections were estimated up to $50 \mathrm{~m}$, using Hammer (1939) charts. Additional terrain corrections, out to a distance of $167 \mathrm{~km}$, were computed using Geosoft in three zones of increasing radius $50 \mathrm{~m}-3 \mathrm{~km}, 3-10 \mathrm{~km}$ and $10-167 \mathrm{~km}$ using three DEMs gridded at $50 \mathrm{~m}, 250 \mathrm{~m}$ and $1 \mathrm{~km}$ respectively. Taking into account the accuracy of the network $(0.1 \mathrm{mGal})$, the repeatability of the gravity measurements $(0.015 \mathrm{mGal})$, the vertical positioning $(0.2 \mathrm{mGal}$ or $0.1 \mathrm{mGal}$ on the detailed profile across the dyke), and the error on terrain corrections $(0.1 \mathrm{mGal})$, the total RMS error on the complete Bouguer anomaly is $0.25 \mathrm{mGal}$ (or $0.17 \mathrm{mGal}$ across the Ile aux Moines dyke). Our new gravity data were then integrated to the available gravity data from the "Banque Gravimétrique de la France" and interpolated on a $300 \mathrm{~m}$ regular grid using a standard minimum curvature algorithm, yielding the complete Bouguer anomaly map of Fig. $8 \mathrm{~b}$.

\subsection{Residual Bouguer anomaly}

In order to highlight the gravity anomaly related to the Carnac Complex, and since the short wavelengths of the gravity anomaly result from shallower bodies (down to a few kilometres), the long wavelengths of the gravity anomaly, have been removed from the complete Bouguer anomaly. At the scale of the entire French Massif Armoricain, a regional Bouguer anomaly has been computed from the BGF French gravity database. After several trials, the long wavelengths of the gravity anomaly, produced by deep structures, such as the Moho interface, have been extracted using a $150 \mathrm{~km}$ Butterworth low-pass filter. Fig. 8a shows the filtered regional Bouguer anomaly, which approximately matches the regional Moho depth variations, in particular in our study area. Removing the regional field to the complete Bouguer anomaly results in the residual Bouguer anomaly of Fig. 8c, which thus mainly reflects the density heterogeneities located in the first kilometres below the topography.

The negative anomalies can be correlated to the granitic bodies, namely the $S^{\text {te }}$-Anne d'Auray magmatic Complex and the Carnac Complex in the northeast and in the southwest of the study area, respectively (Fig. 8c). The gravity study of the $S^{\text {te }}$-Anne d'Auray magmatic complex is beyond the scope of this survey, therefore hereafter our discussion will focus on 
the Carnac Complex. The negative anomaly associated to the Carnac Complex exhibits an asymmetric shape elongated along the WNW-ESE trend. The western part of the Carnac Complex displays the highest negatives anomalies suggesting thickening of the Carnac granite to the west than to the east (Fig. 8c). Positive anomalies can be correlated to the presence of migmatites. The WNW-ESE elongated migmatites domain located between the Carnac Complex and the $\mathrm{S}^{\mathrm{te}}$-Anne d'Auray magmatic complex, and to the east, the Golfe $\mathrm{du}$ Morbihan migmatitic area are both outlined by strong positive anomalies (Fig. 8c).

In order to emphasize the contact between the Carnac Complex and the migmatitic host rock, the vertical gradient of the residual Bouguer anomaly was computed. The negative gradients can be correlated to the presence of granite; conversely, the positive gradient can be correlated to the presence of migmatites. To the south of the Carnac Complex, despite the presence of the sea, preventing the acquisition of additional gravity data far away from the Carnac Complex, several gravity stations constrain the location of the southern boundary between the Carnac Complex and the migmatite host rock. In general, this boundary exhibits well-defined gradients, which suggest steep contacts between the two geological formations. Details of the Carnac Complex geometry such as the NNE-SSW trending indentations in the northern part of the Carnac Complex are reflected in the map of the vertical gradient (Fig. 8d). It is worth noting that the gravity anomalies are not located directly above the indentations but are rather shifted westward, suggesting a westward dip of the NNE-SSW striking Carnac Complex borders.

\subsection{D gravity modelling of the Carnac Complex}

\subsubsection{Modelling constraints}

In order to propose the most realistic gravity model, forward modelling of the gravity data was performed, taking into account the geological field observations, the available geological maps, and density measurements of the formations encountered in the study area.

Representative densities for all the geological formations have been measured by the doubleweighing method. Results are summarized in Fig. 9. An average density of the Carnac granite was obtained using 6 samples taken within the pluton and the dyke swarm. The average calculation clusters around $2.64 \mathrm{~g} / \mathrm{cm}^{3}$, with quite similar densities for the 6 samples, showing that the density is very constant along the Carnac Complex. Moreover, there is no density difference between the pluton and the dyke swarm. At the scale of the study area, the calculation of a representative average density for the migmatites is complicated by the lithological heterogeneity of the protolith. A weighted average density of $2.72 \mathrm{~g} / \mathrm{cm}^{3}$ was obtained for the migmatites taking into account the relative proportion of the different migmatitic rock-types encountered in the field. 


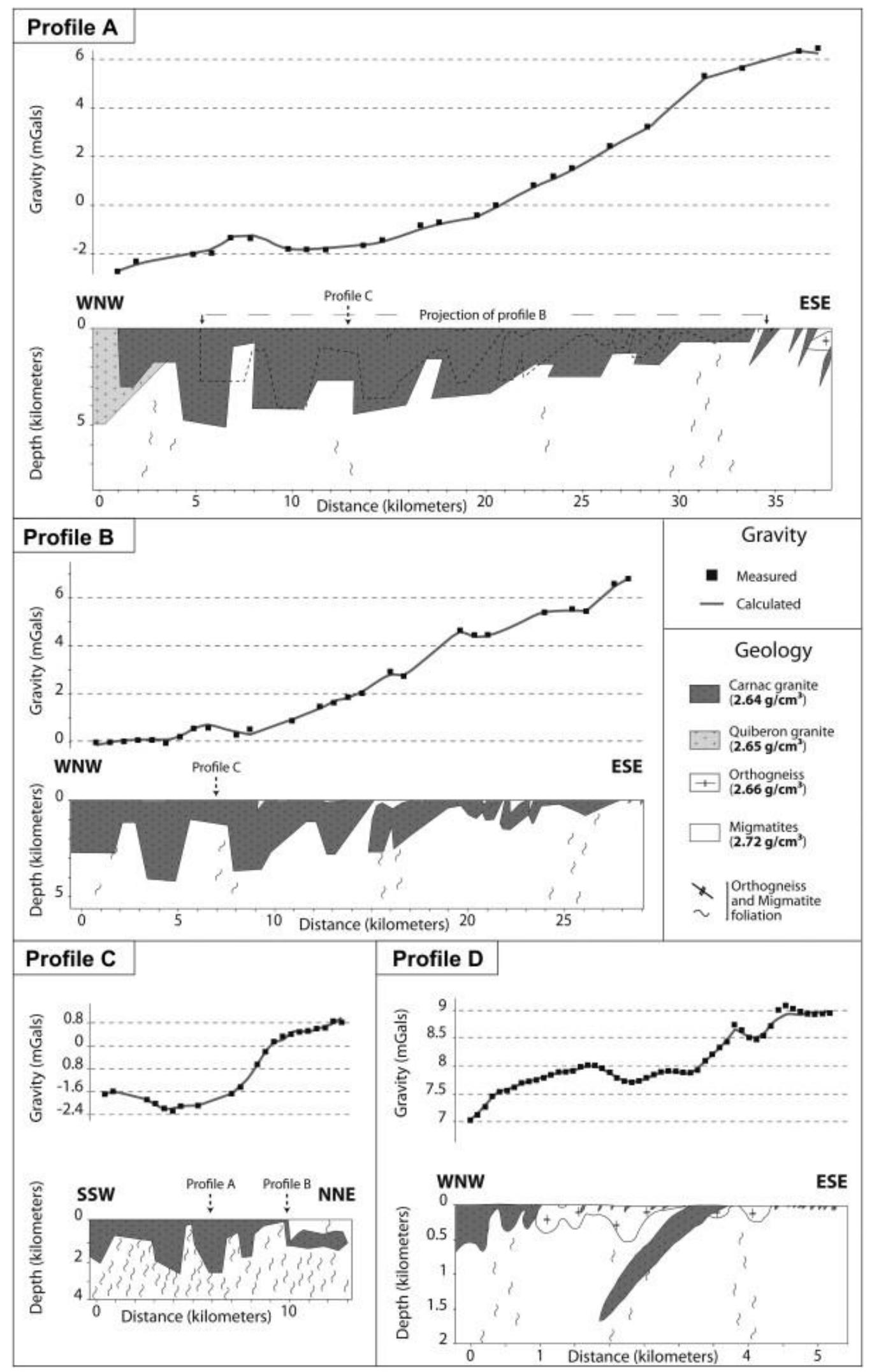

Fig. 9. : Forward 2.5D gravity modelling of the Carnac Complex along WNW-ESE and NNE-SSW cross-sections showing the typical geometry of the Carnac Complex with several deep zones interpreted as feeder zones of the pluton. Modelled density values are provided. 
The relatively high-density contrast between the two main geological formations (i.e. Carnac Complex and migmatites) gives a good confidence in the modelling of the granite. Modelling tests show that uncertainties of $0.01-0.02 \mathrm{~g} / \mathrm{cm}^{3}$ on the density contrast between the Carnac granite and migmatites shift the bottom interface of the granite of less than $500 \mathrm{~m}$, without changing its overall shape.

\subsubsection{D modelling}

The 2D models were performed across the Carnac Complex along WNW-ESE and ENE-SSW trending profiles. A high-resolution modelling of the Ile au Moines dyke was also performed. The location of the profiles is displayed on Fig. 8d. The models were computed in " $2.5 \mathrm{D}$ ", which means that extension of the bodies perpendicularly to the profiles can be controlled. In order to avoid edge effects, the models were extended about $20 \mathrm{~km}$ on each end of the profiles to take into account the influence of nearby geological formations.

The WNW-ESE trending A and B profiles are parallel to the direction of the Carnac Complex elongation, and to the regional stretching, and perpendicular to the dyke direction. Profile A provides an overall image of the Carnac Complex depth variations from west to east, already suggested by the residual Bouguer anomaly. Profile B aims to model the geometry of the NNE-SSW trending indentations. Profile $\mathrm{C}$ trends NNE-SSW perpendicular to the elongation of the Carnac Complex and was modelled in order to better constrain the A and B profiles. Profile D aims to characterize the shape, dip, and vertical extent of the Ile aux Moines dyke.

The most striking feature of our 2D models is the thickness variation of the Carnac Complex (Fig. 10). Gravity models along the WNW-ESE trending A and B profiles both underline an overall eastward thinning of the Carnac Complex, which complies with the eastward decrease of the gravity anomaly (Fig. 8c). Furthermore, several deepening zones can be outlined on both profiles. In profile A, the depth of these deep zones ranges from $\sim 5 \mathrm{~km}$ to the west to $\sim 2.5 \mathrm{~km}$ to the east, which is in the range of the thickness obtained for the deep zones on the west of the profile B. Profile B shows a general picture of the NNE-SSW indentation geometry displayed on the northern boundary of the Carnac Complex. To the east of the profile, the deep zones are shallower than to the west, and dip to the west, parallel to the dykes exposed at the surface. In both profiles, the deep zones and the indentations located to the SE are slightly dipping westward. The NNE-SSW trending profile C shows rather important thickness variations of the Carnac Complex. Along this profile, the deep zones are vertical. On profile D, the Ile aux Moines dyke dips 50-60 ${ }^{\circ}$ to the west, with a width around $500 \mathrm{~m}$ and a maximum depth around $1.5 \mathrm{~km}$.

Despite the relatively smooth amplitude variations of the measured anomaly, significant thickness variations of the Carnac Complex are necessary to fit the gravity anomaly. This irregular geometry is recognized in all the gravity profiles constructed in the Carnac Complex (Fig. 9). The models show a good agreement between the modelled and measured gravity data, except in profile D for the positive anomaly located east of the Ile aux Moines dyke (Fig. 9, profile D). Field observations have shown that the migmatites derive from various protoliths, which is responsible for large variations around the average value of $2.72 \mathrm{~g} / \mathrm{cm}^{3}$ for the bulk migmatites. However, the cartographic extent of these rocks is not well constrained at the surface (i.e. on the map) due to poor outcropping conditions, and therefore we chose not to individualize them in our modelling. These models are possible solutions that i) transcribed the measured anomalies and ii) are supported by field observations, structural measurements and the geological maps (e.g. Augier et al., in press). 


\section{Interpretations and discussion}

\subsection{Significance of the magnetic fabric}

According to the magnetic mineralogical investigations, biotite appears as the main carrier of the magnetic susceptibility. Therefore, the magnetic fabrics measured within the magmatic complex during the AMS survey can be directly correlated to the magmatic fabrics of the main granite body. Within the magmatic complex, the magnetic lineation clusters around two perpendicular directions (Fig. 5b). Taking into account the regional consistency of the AMS lineation with the regional WNW-ESE stretching structures (Fig. 1b), the WNW-ESE magnetic lineation likely developed during the regional deformation. Conversely, the NNESSW striking lineation is parallel to the dyke trend, thus the acquisition of this magnetic linear fabric cannot be interpreted as a response to a WNW-ESE stretching, but rather to magmatic flow during dyke emplacement.

These two sets of magnetic lineation directions are also highlighted by the detailed AMS study across two large-scale dykes (Fig. 6 and Fig. 7). In the core of the dykes, the AMS prolate fabrics are dominated by a WNW-ESE lineation interpreted also as the result of the regional stretching. Within $20 \mathrm{~m}$ of the dyke margins, the shape of AMS ellipsoid becomes oblate, and the magnetic foliation becomes parallel to the margin (Fig. 6). Moreover, when approaching the dyke walls, the mean magnetic lineation shows an orientation close to NNESSW, i.e. parallel to the dyke strike, but with a variable dip (Fig. 6 and Fig. 7).

It has been previously reported that the larger face of the platy magnetic minerals such as biotite, tends to be oriented parallel to the dyke walls during the magmatic filling of a dyke (e.g. [Ellwood, 1978] , [Rochette et al., 1991] , [Raposo, 1997] and [Herrero-Bervera et al., 2001] ). Site 41 , located in a $\sim 15 \mathrm{~m}$-thick dyke, illustrates well such a magnetic pattern (Fig. 10). It shows a typical oblate fabric with well-grouped K3 and largely variable K1. Being consistent with the margin geometry, its vertical foliation may suggest that the magnetic fabric was acquired during dyke filling, and thus it is controlled rather by the magmatic flow along the border than by the regional deformation (Fig. 10). These results are consistent with previous AMS studies from mafic dykes ( [Geoffroy et al., 2002] and [Callot and Guichet, 2003] ), and also acidic dykes (e.g. Talbot et al., 2005b). Following this view, the NNE-SSW trending magnetic lineations measured within the magmatic complex could be interpreted as the evidence of the presence of dykes within the pluton, even if they are not entirely mapped due to poor outcropping conditions (Fig. 10). Moreover, in the dykes, the representative AMS foliation within dykes is flat-lying with a low dip lineation (Fig. 6). The presence of sub-horizontal fabrics within the main pluton does not preclude the existence of dykes, even if these bodies are not recognized in the field. 


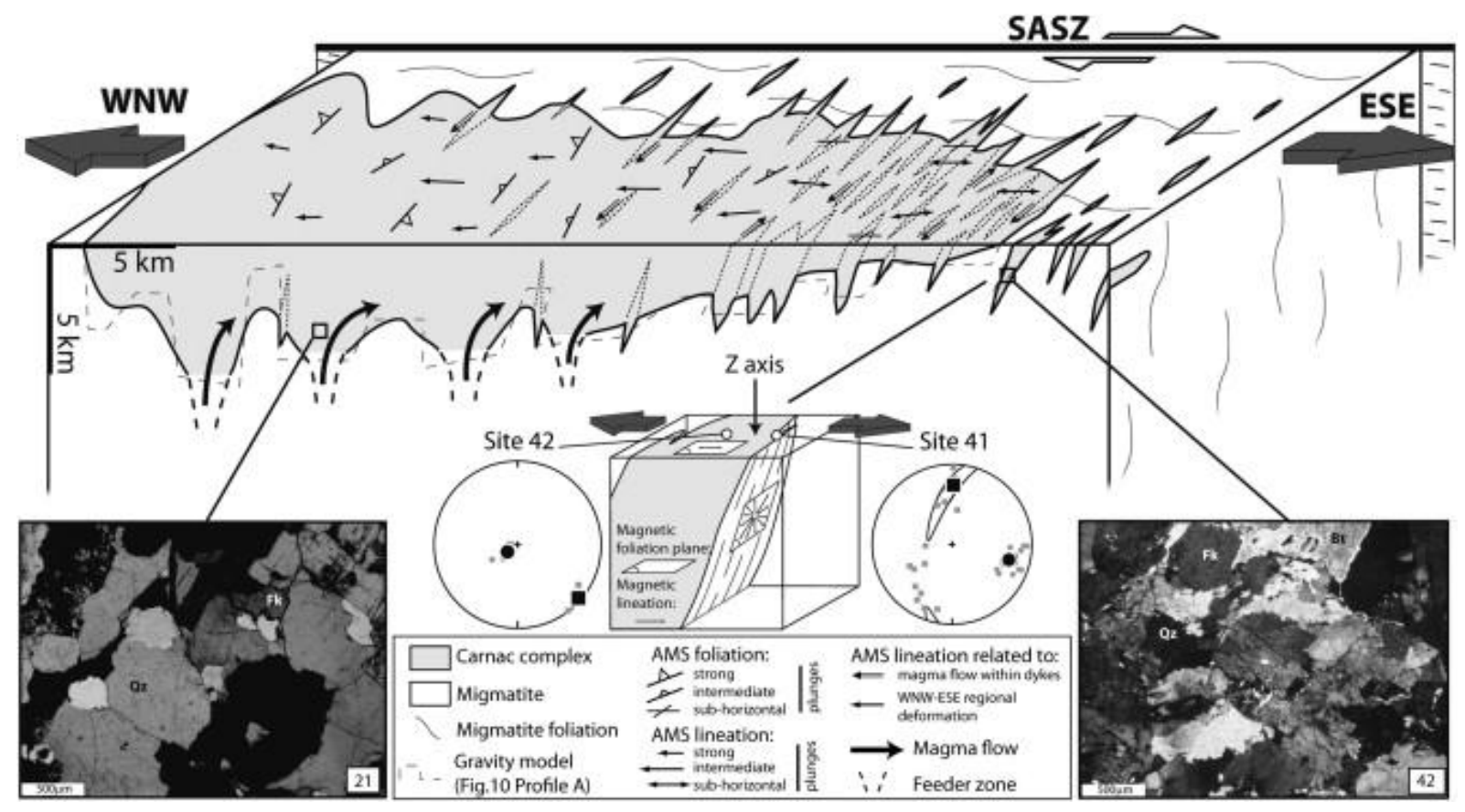

Fig. 10. : Three dimensional schematic representation of the Carnac Complex showing the main structural features inferred from AMS and gravity surveys, microstructural observations of the Carnac granite and dyke (numbers refer to AMS sites). The close up is a block diagram illustrating the magnetic fabric within a dyke in which two representative AMS data sites located at the dyke centre and margin are depicted. The NNE-SSW trending indentations of the Carnac pluton are lateral equivalent of the dykes widespread to the east of the Carnac Complex. Thick arrows represent interpreted magma flow during the Carnac pluton emplacement.

\subsection{Interpretation of the gravity models}

As suggested by the geological map (Fig. 1b), the gravity study shows that the pluton in the western part of the magmatic complex (Fig. 9 profiles A and B), spatially evolves to a dyke swarm well exposed in its eastern part (Fig. 9 profile B). The residual Bouguer anomaly (Fig. 8c) shows that the complex presents an overall eastward thinning. This is supported by the gravity models, showing that the pluton thickness decreases from $\sim 5 \mathrm{~km}$ to $\sim 1 \mathrm{~km}$ from west to east, respectively. In these models, the pluton floor adopts an irregular geometry, highlighting several deep zones characterized by a high-angle westward dip.

As indicated by the projection of profile B on profile A, in the western part of the complex (Fig. 9), the deep zones displayed on both profiles can be laterally correlated. Again, the main pluton floor consists of an irregular surface made by the alternation of several deep and shallow zones elongated along the NNE-SSW direction. The NNE-SSW trending profile also shows important depth variations of the Carnac pluton floor (Fig. 10, profile C). This suggests that the deep zones are not straight along the NNE-SSW direction but undulated. Whatever their exact geometry, these deep zones are interpreted as the feeder zones of the pluton. 


\subsection{Architecture and emplacement model of a syntectonic magmatic complex}

The new gravity and AMS results constrain the Carnac Complex overall shape at depth. These data allow us to determine with a good precision the spatial extent and relative proportion of the pluton and dyke swarm, from west to east of the complex.

To the west, the geological map (Fig. 1b) shows that the dykes are rare. The steeply dipping WNW-ESE magnetic lineation is well developed in the western sector of the pluton (Fig. 5b). This magnetic fabric pattern, which is spatially correlated with the deep zones outlined by the gravity models, is consistent with the existence of the pluton feeder zones in the western part of the complex (Fig. 10). Such evidence of steep lineations, associated with a deepening of the pluton floor, is classically interpreted as significant of the presence of feeder zones (e.g. [Guillet et al., 1985] , [Vigneresse, 1995] , [Améglio et al., 1997] and [Vigneresse and Bouchez, 1997] ).

The northwestern margin of the complex shows NNE-SSW indentations that can be interpreted as apexes of the pluton or dykes (Fig. 1b). In map view, the NNE-SSW indentations are comparable to the largest dykes outcropping eastward in the Golfe du Morbihan area. Related to these indentations, a steep westward dip of the granite-migmatite interface may be suggested by the vertical gradient map of the residual Bouguer anomaly (Fig. 8d), which is similar to the Ile aux Moines dyke dip attitude (profile D in Fig. 9). Based on these observations, the NNE-SSW indentations are interpreted as dyke contributions.

Therefore, the central part of the complex might be constituted by the merging of a pluton and NNE-SSW trending dykes (Fig. 10). The presence of dykes in this part of the complex is also documented by the AMS survey showing numerous NNE-SSW trending magnetic lineations within the pluton (Fig. 5b). The structural and chronological relationships between the pluton and the dykes will be discussed below.

To the east, where the pluton gets thinner (Figs. 9c and 10), the AMS fabric measurements suggest the presence of a great amount of dykes, since the magnetic linear fabric show low dip attitude (Fig. 5b). This assumption is supported by the gravity modelling along the eastern part of the profile B (Fig. 9). There, the Carnac Complex might be constituted by the coalescence of numerous NNE-SSW oriented dykes, rather than by a single pluton (Fig. 10). Due to poor outcropping conditions, the dykes are not mapped; however, more to the east, towards the Golfe du Morbihan, dykes progressively become individualized, as shown in the geological map (Fig. 1b).

As described above, the microstructures of the granitic complex formed under super-solidus (i.e. magmatic) to sub-solidus conditions. Magmatic microstructures are widespread in places where feeder zones of the pluton have been identified by the gravity and AMS surveys (Figs. 2c and d and 10). Thus, in the feeder zones, the magnetic fabric which is consistent with a regional WNW-ESE stretching, likely developed during a magmatic flow. Within the dykes, the magnetic fabrics are also consistent with a regional WNW-ESE stretching, but conversely to the pluton, the dykes experienced a solid-state deformation developed in a later mylonitic stage, as documented by the ca. $302-300 \mathrm{Ma}{ }^{40} \mathrm{Ar} /{ }^{39} \mathrm{Ar}$ ages obtained on white micas (Turrillot, 2010). This microstructural study is consistent with field structural observations, showing that some dykes are penetratively deformed, with a WNW-ESE mineral elongation, which is interpreted as the result of a ductile stretching. 
Based on the AMS, gravity modelling, field structural analyses, and microscopic textural observations, an emplacement model can be proposed for the Carnac Complex (Fig. 10). During the regional tectonics, large extensional fractures, forming the feeder zones of the Carnac pluton, opened perpendicular to the WNW-ESE regional maximum stretching. From a metamorphic study of the Golfe du Morbihan migmatites, Brown and Dallmeyer (1996) proposed that the complex emplaced under pressure and temperature conditions of $\sim 4 \mathrm{kbar}$ and $700-750{ }^{\circ} \mathrm{C}$, respectively. Since the feeder zones deepen to $\sim 5 \mathrm{~km}$ from the present exposed level, the paleo-depth of the feeder zones can be bracketed at $\sim 15 \mathrm{~km}$. The stretching of the crust solved the "room problem" (Bowen, 1948) and allowed a large volume of magma to raise through the feeder zones from a $\sim 15 \mathrm{~km}$ deep level. From these injection zones, the magma gathered to give rise to a single pluton in the western part of the complex (Fig. 10). In an extensional tectonic setting, a similar mechanism of pluton construction has been proposed by D'Eramo et al. (2006) to account for the formation of the El Hongo pluton in the Sierras Pampeanas of Argentina. In the Variscan Central Iberian Massif, the Carboniferous Extremadura batholith also provides an example of pluton emplacement in relation with shearing in an extensional setting (e.g. Fernandez and Castro, 1999). The westward steep dip of the magnetic lineation that developed during a magmatic flow, and the overall westward steeply dipping attitudes of the feeder zones suggest that the magma migrates eastward during the pluton formation (Fig. 10). For the eastward parts of the complex, the migration might be explained by an overall top-to-the-ESE sense of shear. The eastward dyke migration would be coeval with fracturing migration. Thus, new magma batches would infill the voids opened to the east. Furthermore, fracturing of the pluton country rock might be enhanced by the overall cooling of the Carnac granite and surrounding migmatites during the coeval exhumation of the Lower Unit (Brown and Dallmeyer, 1996) that induced a change in the crustal rocks rheology. Then, part of the WNW-ESE regional stretching was accommodated by the opening of large-scale "tension gashes" coevally infilled by the Carnac granite, which resulted in the formation of a pervasive dyke swarm. Strain is also pervasively accommodated by the ductile deformation that concentrated into the dykes during and after the crystallisation of the granite, leading to the solid-state deformation microstructures and sub-horizontal magnetic fabric acquisition within the dykes. A possible gentle tilting of the entire Carnac Complex after its emplacement can not be excluded since most of the dykes present a steep westward dip (i.e. $82 \pm 8^{\circ}$ ). Furthermore, the observed subsequent solid state of deformation which is particularly developed over the main shear zones may have produced a limited rotation by simple shear. Considering the additive contributions of rigid titling and pervasive simple shear and on the basis of the only criterion of the non vertical attitude of the dykes, rotation did not exceeded ca. $8^{\circ}$.

\subsection{Regional tectonic implications}

The South Armorican Domain experienced a WSW-ENE orogen-parallel extensional tectonics during its late evolution. The WNW-ESE extensional tectonics is regarded as responsible for the formation of ductile shear zones (i.e. QSZ and SSZ in Fig. 1b) that favoured the exhumation of the Lower Unit ( [Gapais et al., 1993] , [Brown and Dallmeyer, 1996] and [Turrillot et al., 2009] ). The WNW-ESE trending South Armorican Shear zone may have played the role of a transfer fault that guided the tectonic escape of the South Armorican Domain (Fig. 10). The Carnac Complex emplaced at ca. $319 \pm 6$ Ma, before the onset of the top-to-the-ESE ductile shearing along the SSZ at ca. $300 \mathrm{Ma}$ ( [Turrillot et al., 2009] , [74] and [4] ). The WNW-ESE elongated shape of the Carnac Complex is consistent with a regional WNW-ESE stretching coeval with its emplacement since this direction can be recognized at the magmatic state in the Carnac granite, in the host rock as controlling the 
opening of the dykes, and in the mylonites along the SSZ (Turrillot et al., 2009). The overall shape of the Carnac Complex is similar to that of the Variscan Saint-Sylvestre leucogranitic pluton in the French Massif Central. It has been shown that this $\sim 5 \mathrm{~km}$ thick pluton is a syntectonic body characterized by a NW-SE stretching lineation, and several NE-SW striking feeder zones. The pluton shape and internal fabrics argue for its emplacement coeval with a regional late-orogenic extensional tectonic setting ( [Faure and Pons, 1991] and [Faure, 1995] ) .

In the Carnac Complex, the sub-horizontal planar fabric argues for a vertical maximum shortening axis (Z-axis of the finite strain ellipsoid, Fig. 10) which is consistent with an overall extensional tectonics. The emplacement of the Carnac Complex dyke swarm can thus be considered as the earliest increment of the orogen-parallel extensional tectonics highlighted in the Morbihan area. Inception of extensional tectonics thus dates back to $\sim 320 \mathrm{Ma}$ and may ends at about 302-300 Ma while strain concentrated over large-scale shear zones ( [Turrillot et al., 2009] and [74] ).

\section{Conclusion}

The Carnac Complex, which consists of a pluton associated to a well-developed dyke swarm, was emplaced in the Late Carboniferous times during the late-orogenic extensional tectonics that has been recognised in most parts of the European Variscan belt. Extensional tectonics, are generally attested by the development of low angle detachment faults, synkinematic plutons, gneiss domes and intramontane basins. To date, in the Massif Armoricain, the age of this event relies on rare radiochronological studies performed on mylonites ( [4] and [74] ) or on conventional thermochronological analyses (Brown and Dallmeyer, 1996). The AMS survey of the Carnac Complex documents the relationships between the early record of regional extension and the magmatic fabrics. This AMS study also outlines the geometric consistency of the magnetic fabrics developed during the magmatic flow processes within the dykes and the pluton. The gravity study provides a model of the overall shape of the magmatic complex displaying a clear eastward thinning. These two geophysical approaches allowed us to describe the overall architecture of a magmatic complex which emplacement is constrained by regional extensional tectonics. At depth, several deep zones, interpreted as the pluton feeder zones have been highlighted in the western part of the complex, whereas in the eastern part, the complex seems to be constructed by the coalescence of numerous dykes. The magnetic fabric as well as the microstructural characteristics of the pluton and dykes led us to propose an emplacement model in a crustal stretching context. The magma of the Carnac pluton spread eastward in response to a possible top-to-the-ESE pervasive shearing. Within an extensional tectonic setting, and coevally with the overall cooling of the crust, the magma rise was channelized along large-scale tension gashes. The shape of the Carnac Complex and its internal fabrics are consistent with a WNW-ESE stretching of the crust. The Carnac Complex emplacement then appears to be the earliest insight of the Variscan extensional tectonics highlighted in the Morbihan area and the South Armorican domain. This study provides a new example of the complex pluton-dyke relationships emplaced in a late-orogenic extensional setting. Although dykes surrounding a granitic pluton are often considered as the latest manifestation of magma emplacement, the example of the Carnac Complex provides evidence that, at least in some cases, dyke coalescence might be a likely mechanism for pluton construction.

\section{Acknowledgments}


The present manuscript benefited of the constructive reviews of Antonio Castro and anonymous reviewer that we would like to acknowledge. We gratefully acknowledge the IPGP, especially M. Diament for the loaning of the gravimeter. The gravity figures and 2.5 models were realized with Geosoft/GM-SYS software.

\section{References}

Améglio et al., 1997 L. Améglio, J.-L. Vigneresse and J.-L. Bouchez, Granite pluton geometry and emplacement mode inferred from combined fabric and gravity data, J.-L. Bouchez, D.H.W. Hutton, W.E. Stephens, Editors, From Segregation of Melt to Emplacement Fabrics, Kluwer Academic Publishers, Dordrecht-Boston-London (1997), pp. 199-214 in Granite.

Audren, 1987 Audren, C., 1987. Evolution structurale de la Bretagne méridionale au Paléozoïque, Ph.D. thesis, Université de Rennes 1, Rennes, pp. 365.

Audren and Le Métour, 1976 C. Audren and J. Le Métour, Mobilisation anatectique et déformation. Un exemple: les migmatites du Golfe du Morbihan (Bretagne méridionale). Bulletin de la Société géologique de France, 4 (1976), pp. 1041-1049.

Augier et al., in press Augier, R., Menier, D., Van-Vliet-Lanoë, B., Hallegouët, B., Chauris, L., Turrillot, P., Carn, A., Thinon, I., in press. Notice explicative de la carte géologique de la feuille Vannes Saint-Gildas de -Rhuys à 1/50000..

Baker, 1998 D.R. Baker, The escape of pegmatite dikes from granitic plutons: constraints from new models of viscosity and dike propagation. The Canadian Mineralogist, 36 (1998), pp. 255-263.

Ballèvre et al., 1994 M. Ballèvre, J. Marchand, G. Godard, J.-C. Goujou and R. Wyns, EoHercynian events in the Armorican Massif, J.D. Keppie, Editor, Pre-Mesozoic Geology in France and Related Areas, Springer, Berlin (1994), pp. 183-194.

Ballèvre et al., 2009 M. Ballèvre, V. Bosse, C. Ducassou and P. Pitra, Palaeozoic history of the Armorican Massif: models for the tectonic evolution of the suture zones. Compte Rendus Géoscience, 341 (2009), pp. 174-201.

Bartley et al., 2006 J.M. Bartley, D.S. Coleman and A.F. Glazner, Incremental pluton emplacement by magmatic crack-seal. Transactions of the Royal Society of Edinburgh: Earth, 97 (2006), pp. 383-396.

Berthé et al., 1979 D. Berthé, P. Choukroune and P. Jégouzo, Orthogneiss, mylonite and non coaxial deformation of granites: the example of south Armoricain shear zone. Journal of Structural Geology, 1 (1979), pp. 31-42.

Borradaile, 1988 G.J. Borradaile, Magnetic susceptibility, petrofabrics and strain. Tectonophysics, 156 (1988), pp. 1-20.

Borradaile and Henry, 1997 G.J. Borradaile and B. Henry, Tectonic applications of magnetic susceptibility and its anisotropy. Earth Science Reviews, 42 (1997), pp. 49-93. 
Bosse et al., 2002 V. Bosse, M. Ballèvre and O. Vidal, Ductile thrusting recorded by the garnet isograd from blueschist-facies metapelites of the Ile de Groix, Armorican Massif, France. Journal of Petrology, 43 (2002), pp. 485-510.

Bouchez, 1997 J.-L. Bouchez, Granite is never isotropic: an introduction to AMS studies of granitic rocks, J.-L. Bouchez, D.H.W. Hutton, W.E. Stephens, Editors , From Segregation of Melt to Emplacement Fabrics, Kluwer Academic Publishers, Dordrecht-Boston-London (1997), pp. 95-112 in Granite.

Bowen, 1948 N.L. Bowen, The granite problem and the method of multiple prejudices, Origin of Granite, 28 ,in: J. Giluly, Editor, et al. Geological Society of America (1948), pp. 79-90 Memoir.

Brown, 1983 M. Brown, The petrogenesis of some migmatites from the Presqu'ile de Rhuys, southern Brittany, France, M.P. Atherton, C.D. Gribble, Editors, Migmatites, Melting and Metamorphism, Shiva Publishing, Nantwich (1983), pp. 174-200.

Brown, 2005 M. Brown, Synergistic effects of melting and deformation: an example from the Variscan belt, Western France, paper presented at 13th Conference Information: Meeting on Deformation Mechanisms, Rheology and Tectonics, (2003), Source: Deformation Mechanisms, Rheology and Tectonics: from minerals to the Lithosphere, 243 Geological Society Special Publication, St Malo, France (2005), pp. 205-226.

Brown and Dallmeyer, 1996 M. Brown and R.D. Dallmeyer, Rapid Variscan exhumation and the role of magma in core complex formation: southern Brittany metamorphic belt, France. Journal of Metamorphic Geology, 14 (1996), pp. 361-379.

Brun and Pons, 1981 J.-P. Brun and J. Pons, Strain patterns of pluton emplacement in a crust undergoing non-coaxial deformation, Sierra-Morena, Southern Spain. Journal of Structural Geology, 3 (1981), pp. 19-229.

Brun and Burg, 1982 J.-P. Brun and J.-P. Burg, Combined thrusting and wrenching in the Ibero-Armorican arc: a corner effect during continental collision. Earth and Planetary Science Letters, 61 (1982), pp. 319-332.

Cagnard et al., 2004 F. Cagnard, D. Gapais, J.-P. Brun, C. Gumiaux and J. Van Den Driessche, Late pervasive crustal-scale extension in the south Armorican Hercynian belt (Vendée, France). Journal of Structural Geology, 26 (2004), pp. 435-449.

Callot and Guichet, 2003 J.-P. Callot and X. Guichet, Rock texture and magnetic lineation in dykes: a simple analytical model. Tectonophysics, 366 (2003), pp. 207-222.

Carpena et al., 1979 Carpena, J., Chaillou, D., Chambaudet, A., Poupeau, G., 1979. Fission Track Geochronology of the Hercynian Platform in France. Report of the 10th International Conference on Solid State Nuclear Track Detectors, Space Biophysics of the Parliament of the Council of Europe, Lyon..

Clemens and Mawer, 1992 J.D. Clemens and C.K. Mawer, Granitic magma transport by fracture propagation. Tectonophysics, 204 (1992), pp. 339-360. 
Cloos, 1925 H. Cloos, Einfurhrung in die tectonische Behandlung magmatischer Erscheinungen. Das Riesengebirge in Shlesien, Gebrüder, Borntraeger, Berlin (1925), pt 1, 194 pp..

Cogné, 1974 Cogné, J., 1974. Le Massif armoricain. In: Debelmas, J. (Ed.). Géologie de la France. Doin, Paris, France, pp. 105-161..

D’Eramo et al., 2006 F. D'Eramo, L. Pinotti, J.M. Tubia, N. Vegas, A. Aranguren, R. Tejero and D. Gomez, Coalescence of lateral spreading magma ascending through dykes: a mechanism to form a granite canopy (El Hongo pluton, Sierras Pampeanas, Argentina), J (2006), London881-892.

Dewey and Burke, 1973 J. Dewey and K.C. Burke, Tibetan, Variscan and Precambrian basement reactivation: products of continental collision. Journal of Geology, 81 (1973), pp. 683-692.

Ellwood, 1978 B.B. Ellwood, Flow and emplacement direction determined for selected basaltic bodies using magnetic susceptibility anisotropy measurements. Earth and Planetary Science Letter, 41 (1978), pp. 254-264.

Faure, 1995 M. Faure, Late orogenic Carboniferous extensions in the Variscan French massif central. Tectonics, 14 (1995), pp. 132-153.

Faure and Pons, 1991 M. Faure and J. Pons, Crustal thinning recorded by the shape of the Namurian-Westphalian leucogranite in the Variscan belt of the northwest Massif Central, France. Geology, 7 (1991), pp. 730-733.

Faure et al., 2005 M. Faure, E. Bé Mézème, M. Duguet, C. Cartier and J.-Y. Talbot, Paleozoic tectonic evolution of medio-Europa from the example of the French Massif Central and Massif Armoricain, Journal of Virtual Explorer Electronic, 19 ,in: R. Carosi, R. Dias, D. Iacopini, G. Rosenbaum, Editors, The Southern Variscan Belt (2005) Paper 5.

Faure et al., 2008 M. Faure, E. Bé Mézème, A. Cocherie, P. Rossi, A. Chemenda and D. Boutelier, Devonian geodynamic evolution of the Variscan belt, insights from the French Massif Central and Massif Armoricain, . Tectonics, 27 (2008) TC2008. doi.org/10.1029/2007TC002115.

Fernandez and Castro, 1999 C. Fernandez and A. Castro, Pluton accommodation at high strain rates in the upper continental crust. The example of the Central Extremadura batholith, Spain. Journal of Structural Geology, 21 (1999), pp. 1143-1149.

Gapais and Barbarin, 1986 D. Gapais and B. Barbarin, Quartz fabric transition in a cooling syntectonic granite (Hermitage Massif, France). Tectonophysics, 125 (1986), pp. 357-370.

Gapais et al., 1993 D. Gapais, J.-L. Lagarde, C. Le Corre, C. Audren, P. Jégouzo, A. Casas Sainz and J. Van Den Driessche, La zone de cisaillement de Quiberon: témoin d'extension de la chaîne Varisque en Bretagne méridionale au Carbonifère. Compte Rendus de l'Académie des Sciences de Paris, 316 (1993), pp. 1123-1129. 
Geoffroy et al., 2002 L. Geoffroy, J.-P. Callot, C. Aubourg and M. Moreira, Magnetic and plagioclase linear fabric discrepancy in dykes: a new way to define the flow vector using magnetic foliation. Terra Nova, 14 (2002), pp. 183-190.

Goujou, 1992 Goujou, J.-C., 1992. Analyse pétro-structurale dans un avant-pays métamorphique: influence du plutonisme tardi-orogénique Varisque sur l'encaissant épi à mésozonal de Vendée, BRGM (Ed.), pp. 216..

Guerrot et al., 1997 C. Guerrot, F. Béchennec and D. Thiéblemont, Le magmatisme paléozoïque de la partie nord-ouest du domaine sud-armoricain données géochronologiques nouvelles. Compte Rendus de l'Académie des Sciences de Paris, 324 (1997), pp. 977-984.

Guillet et al., 1985 P. Guillet, J.L. Bouchez and J.L. Vigneresse, Le complexe granitique de Plouaret: mise en évidence structurale et gravimétrique de diapirs emboités. Bulletin de la Société Géologique de France, 8 (1985), pp. 503-513.

Hammer, 1939 S. Hammer, Terrain corrections for gravimeter stations. Geophysics, 4 (1939), pp. 184-194.

Harris and Massey, 1994 N. Harris and J. Massey, Decompression and anatexis of Himalayan metapelites. Tectonics, 13 (1994), pp. 1537-1546.

Herrero-Bervera et al., 2001 E. Herrero-Bervera, G.P.L. Walker, E. Canon-Tapia and M.O. Garcia, Magnetic fabric and inferred flow direction of dikes, conesheets and sill swarms, Isle of Skye, Scotland. Journal of Volcanology and Geothermal Research, 106 (2001), pp. 195210.

Hrouda, 1982 F. Hrouda, Magnetic anisotropy of rocks and its application in geology and geophysics. Geophysical Surveys, 5 (1982), pp. 37-82.

Jégouzo, 1980 P. Jégouzo, The South Armorican shear zone. Journal of Structural Geology, 2 (1980), pp. 39-47.

Jégouzo et al., 1986 P. Jégouzo, J.-J. Peucat and C. Audren, Caractérisation et signification géodynamique des orthogneiss calco-alcalins d'âge ordovicien de Bretagne méridionale. Bulletin de la Société Géologique de France, 2 (1986), pp. 839-848.

Jelinek, 1978 V. Jelinek, Statistical processing of anisotropy of magnetic susceptibility measured on groups of specimens. Studia Geophysica et Geodaetica, 22 (1978), pp. 50-62.

Jelinek, 1981 V. Jelinek, Characterization of the magnetic fabric of rocks.

Tectonophysics, 79 (1981), pp. 563-567.

Johnson and Brown, 2004 T. Johnson and M. Brown, Quantitative constraints on metamorphism in the Variscides of southern Brittany - a complementary pseudosection approach. Journal of Petrology, 45 (2004), pp. 1237-1259.

Jones and Brown, 1989 K.A. Jones and M. Brown, The metamorphic evolution of the Southern Brittany Migmatites Belt, Geological Society Special Publication, 43 ,in: J.S. Daly, R.A. Cliff, B.W.D. Yardley, Editors, Evolution of Metamorphic Belts (1989), pp. 501-505. 
Jones and Brown, 1990 K.A. Jones and M. Brown, High-temperature 'clockwise' P-T paths and melting in the development of regional migmatites: an example from southern Brittany, France. Journal of Metamorphic Geology, 8 (1990), pp. 551-578.

Le Corre et al., 1991 C. Le Corre, B. Auvray, M. Ballevre and M. Robardet, Le Massif Armoricain. Scientifical Geological Bulletin, 44 1-2 (1991), pp. 31-103.

Le Fort, 1981 P. Le Fort, Manaslu leucogranite: a collision signature in the Himalaya, a model for its genesis and emplacement. Journal of Geophysical Research, 86 (1981), pp. 1054510568 .

Le Hébel, 2002 Le Hébel, F., 2002. Déformation continentale et histoire des fluides au cours d'un cycle subduction, exhumation, extension. Exemples des porphyroides sud-armoricains. Ph.D. thesis. Université de Rennes, Rennes 1. pp. 250..

Le Hébel et al., 2002 F. Le Hébel, O. Vidal, J.-R. Kienast and D. Gapais, Les 'Porphyroides' de Bretagne méridionale: une unité de HP-BT dans la chaine hercynienne. Compte Rendus Géoscience, 334 (2002), pp. 205-211.

Le Métour, 1977 J. Le Métour, Petrogenesis of migmatites and associated granites in South Brittany. Neuse Jahrbuch Mineralogie - Monatshefte, 8 (1977), pp. 364-376.

Lister et al., 1984 G.S. Lister, G. Banga et and A. Feenstra, Metamorphic core complexes of cordilleran type in the Cyclades, Aegean Sea, Greece. Geology, 12 (1984), pp. 221-225.

Malavieille, 1993 J. Malavieille, Late orogenic extension in mountain belts: Insights from the Basin and Ranges and the Late Paleozoic Variscan Belt. Tectonics, 12 (1993), pp. 11151130.

Marchildon and Brown, 2003 N. Marchildon and M. Brown, Spatial distribution of meltbearing structures in anatectic rocks from southern Brittany, France: implications for melttransfer at grain-scale to orogen-scale. Tectonophysics, 364 (2003), pp. 215-235.

Matte, 1986 P. Matte, La chaîne Varisque parmi les chaînes Paléozoïques péri atlantiques, modèle d'évolution et position des grands blocs continentaux au Permo-Carbonifère. Bulletin de la Société Géologique de France, 2 (1986), pp. 9-24.

Matte, 1991 P. Matte, Accretionary history and crustal evolution of the Variscan belt in Western Europe. Tectonophysics, 196 (1991), pp. 309-337.

Matte, 2001 P. Matte, The Variscan collage and orogeny (480-290 Ma) and the tectonic definition of the Armorica microplate: a review. Terra Nova, 13 (2001), pp. 122-128.

Passchier, 1990 C.W. Passchier, Reconstruction of deformation and flow parameters from deformed vein sets. Tectonophysics, 180 (1990), pp. 185-199.

Paterson et al., 1989 S.R. Paterson, R.H. Vernon and O.T. Tobisch, A view of criteria for the identification of magmatic and tectonic foliations in granitoids. Journal of Structural Geology, 11 (1989), pp. 349-363. 
Petford, 1996 N. Petford, Dykes and diapirs?. Transaction Royal Society Edinburgh Earth Science, 87 (1996), pp. 105-114.

Petford et al., 1993 N. Petford, R.C. Kerr and J.R. Lister, Dike transport of granitoid magmas. Geology, 21 (1993), pp. 845-848.

Petford et al., 2000 N. Petford, A.R. Cruden, K.J.W. McCaffrey and J.-L. Vigneresse, Granite magma formation, transport and emplacement in the Earth's crust. Nature, 408 (2000), pp. 669-6673.

Peucat, 1983 J.-J. Peucat, Géochronologie des roches métamorphiques ( $\mathrm{Rb}-\mathrm{Sr}$ et U-Pb). Exemples choisis au Groënland, en Laponie, dans le Massif armoricain et en Grande Kabylie. Mémoire de la Société Géologique et Minéralogique de Bretagne, 28 (1983), p. 158.

Raposo, 1997 M.I.B. Raposo, Magnetic fabric and its significance in the Florianopolis dyke swarm, Southern Brazil. Geophysical Journal International, 131 (1997), pp. 159-170.

Rochette et al., 1991 P. Rochette, L. Jenatton, C. Dupuy, F. Boudier and I. Reuber, Emplacement modes of basaltic dykes in the Oman ophiolite: Evidence from magnetic anisotropy with reference to geochemical studies, T.J. Peters, Editor, Ophiolite Genesis and the Evolution of the Oceanic Lithosphere, Kluwer, Dordrecht (1991), pp. 55-82.

Rochette et al., 1992 P. Rochette, M. Jackson and C. Aubourg, Rock magnetism and the interpretation of anisotropy of magnetic susceptibility. Reviews of Geophysics, 30 (1992), pp. 209-226.

Rubin, 1995 A.M. Rubin, Getting granite dikes out of the source region. Journal of Geophysical Research, 100 (1995), pp. 5911-5929.

Talbot et al., 2005a J.-Y. Talbot, M. Faure, Y. Chen and G. Martelet, Pull-apart emplacement of the Margeride granitic complex (French Massif Central). Implications for the late evolution of the Variscan orogen. Journal of Structural Geology, 27 (2005), pp. 1610-1629.

Talbot et al., 2005b J.-Y. Talbot, Y. Chen and M. Faure, Pluton-dykes relationships from AMS and microstuctural studies in a Variscan granite from French Massif Central. Journal of Geophysical Research, 110 (2005), p. B12106 doi:10.1029/2005JB003699.

Triboulet and Audren, 1988 C. Triboulet and C. Audren, Controls on P-T-t-deformation path from amphibole zonation during progressive metamorphism of basic rocks (estuary of the river Vilaine, south Brittany, France). Journal of Metamorphic Geology, 6 (1988), pp. 117133.

Turrillot, 2010 Turrillot, P., 2010. Fusion crustale et évolution tardi-orogénique du Domaine Sud Armoricain. Ph.D. thesis. Université d'Orléans, pp. 364..

Turrillot et al., 2009 P. Turrillot, R. Augier and M. Faure, The top-to-the-southeast Sarzeau shear zone and its place in the late-orogenic extensional tectonics of Southern Armorica. Bulletin de la Société Géologique de France, 180 (2009), pp. 247-261 
Vauchez et al., 1987 A. Vauchez, D. Maillet and J. Sougy, Strain and deformation mechanisms in the Variscan nappes of Vendé, South Brittany, France. Journal of Structural Geology, 9 (1987), pp. 31-40.

Vigneresse, 1995 J.L. Vigneresse, Control of granite emplacement by regional deformation. Tectonophysics, 249 (1995), pp. 173-186.

Vigneresse and Bouchez, 1997 J.-L. Vigneresse and J.-L. Bouchez, Successive granitic magma batches during pluton emplacement: the case of Cabeza de Araya (Spain). Journal of Petrology, 38 (1997), pp. 1767-1776.

Watts and Williams, 1979 M.S. Watts and G.D. Williams, Faults rocks as indicators of progressive shear deformation in the Guingamp region, Brittany. Journal of Structural Geology, 1 (1979), pp. 323-332.

Wernicke, 1981 B. Wernicke, Low-angle normal faults in the Basin and Range Province: nappe tectonics in an extending orogen. Nature, 291 (1981), pp. 645-648

Whitney et al., 2004 D.L. Whitney, C. Teyssier and C.S. Siddoway, Geological Society of America (2004), Special Paper, pp. 393. 